\title{
STUDIES OF SULFUR IN RELATION TO THE SOIL SOLUTION
}

BY

WILBUR L. POWERS

\section{CONTENTS}

Introduction - PAGG

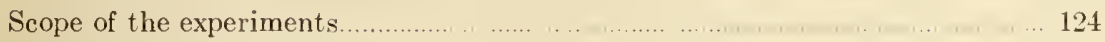

Relation of replaceable bases and sulfofication to the soil solution.......... 125



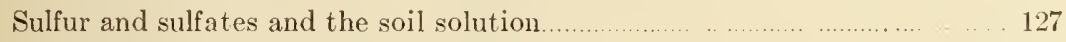

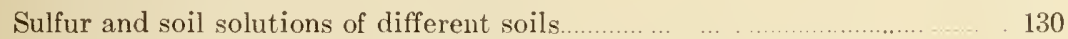

Sulfur and alfalfa yield with soils in jars .................................. 133

Hydrogen ion concentration in cropped and fallow soil pots ............... 134

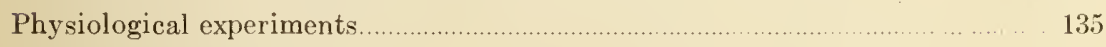

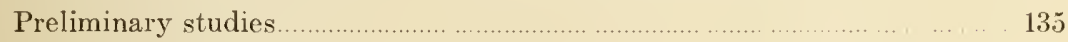

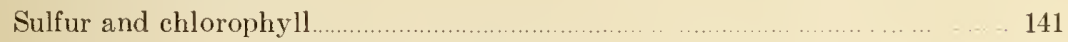

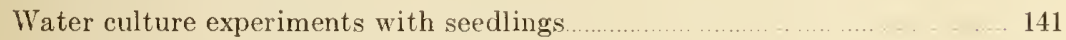

How does sulfur go into the plants? ..................................... 142

Calcium sulfate versus potassium sulfate $\ldots \ldots \ldots \ldots \ldots \ldots \ldots \ldots \ldots \ldots \ldots \ldots \ldots \ldots . . . . . . . . . . . .143$

Complete nutrient solution versus displaced soil solution $\ldots \ldots \ldots \ldots \ldots \ldots \ldots . . \ldots . . .146$

When does alfalfa most need sulfur?

Crop-producing power of limited amounts of sulfur with alfalfa $\ldots . . . . \ldots . .150$

Concentration of sulfate needed for optimum growth of alfalfa? .............. 152

Sulfate concentration experiments with culture solutions ..................... 155

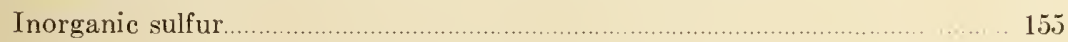

Yield and inorganic sulfate content as affected by sulfate concentration ... 157

Sulfate concentration experiment with solid culture mediun ...................... 159

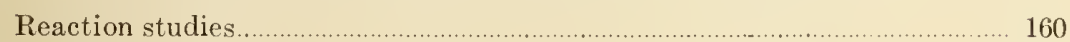

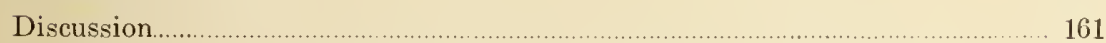

Is sulfate concentration in soil solutions sometimes too low for best growth? 161

Does sulfur serve to hold calcium and other bases in solution?................ 162

Will the average application of sulfur hasten soil deterioration? .............. 164

Does sulfur improve reaction of arid soils for alfalfa?.............................. 164

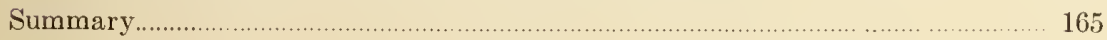




\section{INTRODUCTION}

Sulfur has given excellent results as a fertilizer for the past twelve years when applied to many of the nearly neutral, semi-arid, basaltic soils of the northwestern United States, especially when used on legumes. More than 120,000 acres in Oregon can be expected, with sulfur, to yield an additional ton an acre of alfalfa a year. One-third of this area has been sulfured.

The reason for the marked increase in yield is not well understood, even though an extensive literature on the agrotechnic use of sulfur has aceumulated. Possible defieiency of sulfur in soils has not been seriously considered until recently when better methods of analyses revealed much larger quantities of sulfur in plant tissue than was reported by earlicr investigators. ${ }^{23}$ Assuming that the quantity of sulfur in plant tissue is an indication of the amount required for normal growth processes, it is readily seen why sulfur is given more consideration than formerly in studies of crop production. The supply of sulfur found in soils by modern methods of analysis ${ }^{51,54}$ emphasizes the relative importance of this element. Elemental sulfur has been extensively studied during the past dozen years in relation to its effect on soils, soil micro-organisms, and plants. The adequacy of the supply of sulphate in the soil solution has been questioned and the study of gains and losses in soil sulfur has been given much attention.

The supply of sulfur in soils is in many instances less than that of phosphorous. ${ }^{50}$ The total sulfur content of normal soils can be expected to range from 300 to 1200 pounds in two million. ${ }^{46,51}$ Many of the surface soils of the northwest contain less than 500 pounds of sulfur in 2,000,000, and often run as low as 100 to 300 pounds in the plowed surface of an acre in leached basaltic land. A six-ton alfalfa crop may remove 30 pounds of sulfur an acre. Certain soils that have been cropped for a generation appear to have lost 20 to 40 per cent of the initial sulfur content. The sulfur content of soils seems to rary with the organic matter supply and is usually largest in the sturface soil.

Analyses of percolate from lysimeters, where the amount drained out annually is not large, may indieate the nature of the soil solution. ${ }^{59}$ The percolate from the Cornell lysimeters contains sulfur lost at the rate of 30 to $4 t$ pounds an acre cach year $;^{46}$ in Iowa, ${ }^{16} 67$ pounds; 
at Rothamsted, ${ }^{46} 71.6$ pounds; at Bromberg, Germany, ${ }^{19}$ about 100 pounds; and in Wisconsin ${ }^{23}$ and at Oregon Experiment Station the loss in drainage has been 15 to 40 pounds an acre a year, or about four times the amount received in precipitation. ${ }^{50}$

The concentration of sulfate ion in water cxtracts of soil has often been 100 parts per million or more and often approximates half the concentration of sulfate in the displaced soil solution. Burd ${ }^{9}$ reports concentrations of sulfate in displaced solutious from California soils of from $1+8$ to 655 parts per million. Sulfate was found to increase in fallow and to help hold eations in solution, especially when nitrates were depleted by crops or redueed by anaerobic bacteria.

The soil solution is not diluted with sulfur-free rain water. Ames and Boltz ${ }^{3}$ present data showing 9 pounds of sulfur per acre in the country and 72 pounds in town reccived annually from rainfall. Different investigators ${ }^{50}$ report determinations showing wide variations between amounts of sulfur thus gained or lost in different sections of the country.

Sulfur is often added to land in barnyard manure, potassium sulfate, ammonium sulfate, commercial "superphosphate," or as calcium sulfate. Especially in southeastern United States, where much commercial fertilizer is used, the practice tends to overeome any possible crop depression from lack of a sufficient concentration of this nutrient in the soil solution. Sulfur seems to be more abundant in soils originating from granitic rock than in soils of basaltic origin. Sulfates may aceumulate with alkali, as in the Great Basin region, owing to absence of chainage for its removal.

Hart and Peterson in $1911^{23}$ announced new figures for the sulfur content of crops, showing that Leguminosae and Cruciferae are especially heavy users of sulfur. Reimer and Tartar ${ }^{51}$ found that a six-ton crop of alfalfa removed about 30 pounds of sulfur an acre. Recent data by Jones ${ }^{32}$ tends to reduce this amount slightly.

One well established function of sulfur is that of increasing the protein content of alfalfa. ${ }^{51,45}$ It is said to be present in the protein eystine. $^{47,53}$ Evidence has been found that the SII group in cystine plays a catalytic rôle in synthesis of vegetable fats in plant cells. ${ }^{44,58}$ Increased root and nodule development ${ }^{22,51}$ and a richer g'cen color have commonly resulted from use of sulfur on alfalfa. Stiffer straw and heavier seed has been noted from sulfur or sulfate applications to grain land ${ }^{15.34}$ Marris et al ${ }^{24}$ reported a higher concentration of sulfate in the leaf-tissue fluids of Upland than of Egyptian entton 
and suggest that this difference may be related to drought resistance, alkali resistanee, and the coneentration of sulfate ions in the soil solution.

Adequate evidence does not secm to have bcen found to establish any close relation between the total sulfur in soils and the sulfate content of the soil solution or sulfate requirement of crops. It seems probable that plants may contain more sulfur than required perhaps both in organic and inorganic form where the sulfate eonecntration of the soil solution with which they are grown is high.

Numerous investigators hare fonnd ${ }^{50}$ that with heavy applieations of sulfur to soils there is an increase in concentration of free hydrogen ions somewhat proportional to the amount of sulfur applied and oxidized to sulfates. Adams ${ }^{1}$ demonstrated that sulfate formed may be leached out, while the acidity is not removed. Hydrogen ion seems to participate in an cxehange for absorbed cations, sueh as calcium ion, permitting the hydrogen ion to remain with the soil as an aeid silicate, while the calcium ion is leached out in association with sulfate. The amount of increase in concentration of hydrogen ions in the soil solution as a result of sulfur applications may depend on the amount of readily soluble bases present and general buffer effects of the soil.

Ijipman, ${ }^{36}$ Kelley, ${ }^{33}$ and other's have suggested sulfur for correeting the reaction of "black alkali" soil by inereasing the hydrogen ion eoneentration upon oxidation and combination with water. This aeid may then dissolve calcium compounds and bring about exchange of such multivalent bases for sodium in the solid phase and thus improve permeability and reaction of "black alkali" land. Johmson and Powers ${ }^{30}$ found sulfur an effective chemical treatnent for such land under eastern Oregon conditions, especially when used in eombination with gypsum or manure. Sulfur may improve the reaction of an alkaline soil, floceulate colloids so as to permit better drainage, and tend to dissolve caleium from its eompounds, all of which may improve soil conditions for legume crops.

The Lipman ${ }^{37,} 38$ process of rendering roek phosphate soluble depends upon the produetion of acid by oxidation of sulfur to produce soluble phosphate. Ijipman and his associates have studied the most economical proportion of soil, sulfur, and "floats," hest suited to moisture and elinutic conditions, for economical production of arailable phosphates. Good results have been secured in western Oregon by applying roek phosphate in combination with sulfur and manure alternated with lime. ${ }^{50} \quad \Lambda$ reeiprocal relation between plosphates and 
calcium in solution in the soil has been shown by Burd ${ }^{8}$ and by Stephenson and Powers. ${ }^{56}$ A moderate increase in acrdity may tend to increase phospliate in the soil solution while higher acidity may increase calcium ions and aluminum ions and precipitate phosphate to a relatively insoluble form.

There has been some controversy as to whether calcium sulfate or sulfur liberates potassium in the soil. According to Lipman and Gericke $^{35}$ this depends mpon the particular soil. Different investigators have reported the potassium content of soil water extracts to be somewhat increased as a result of sulfur or sulfate applications. ${ }^{16,41,46}$

MacIntire ${ }^{39}$ has pointed out a relation of sulfur applications to increased loss of calcium in percolate from lysimeters. 'This relation has been found to hold true with two Oregon soils cmployed in lysimeters at Oregon Experiment Station. Adams ${ }^{1}$ hell that it was difficult to find much calcium in solution in acid soils with a lydrogen ion concentration as great as pll 5.0. Stephenson and l'owers ${ }^{36}$ found that the most striking effect of sulfur on water extracts of three soils tested was the increase in calcium ion in solution. This effect would be expected to be less marked upon acid soils which have been rather thoroughly leached of soluble calcium compounds.

Nitrification and sulfofication largely result from biological activities. A little sulfur may stimulate ammonification. ${ }^{49}$ Sulfur may oxidize and unite with ammonia as sulfate of ammonia. ${ }^{2} \mathrm{MeCool}^{43}$ finds that sulfur aids decomposition of organic matter and formation of nitrates. A little sulfur appears to aid nodule devclopment ${ }^{49,}, 1$ and nitrification ${ }^{ \pm 5,46}$ in arid soils, while larger applications may result in increasing the hydrogen ion concentration sufficiently to depress nitrogen fixation and nitrification. Rudolfs ${ }^{54}$ observed five times more bacteria in alkaline soil that was neutralized by sulfur. Burd and Martin ${ }^{11}$ have noted a reciprocal relation between the amount of nitrates and sulfates obtained in the soil solution. Whenever sulfur stimulates growth of legumes an increase may be expected in nitrogen supply in the soil and of nitrate in the soil solution.

Recent investigations lead to the conclusion that the supply of available sulfur, like the supply of available nitrogen, follows a fairly definite cycle. Joffe ${ }^{29}$ concludes that making acid phosphate by the Lipman process is chicfly a problem of providing favorable conditions for sulfur oxidation. Brown and Kellogg find that soils have a fairly definite sulfur oxidizing power. ${ }^{6}$ Lipman and McLean ${ }^{38}$ report that 
temperature, aeration, moisture content, and proportion of materials affeet sulfur oxidation, and they find no advantage in starting sulfur oxidation with a soil of high aeidity. Halversen and Bollen ${ }^{21}$ report that sulfur application inereases the sulfur oxidizing power of soils; they find little need for inoculated sulfur for many Oregon soils. It appears that heavy textured soil is unfavorable and good organie supply is farorable to rapid sulfur oxidation in soils. Brown and Gwinn ${ }^{5}$ note that phosphorus and manure increase sulfofication in loam soils. Stephenson ${ }^{59}$ has reeently demonstrated that the rate of sulfur oxidation is related to the surfaee area and that sulfur, ground to pass a forty-mesh sieve, should oxidize at a rate adequate to meet plant needs. Boullanger and Dugardin ${ }^{4}$ suggest that eertain sulfur eompounds are oxidation eatalysts. The possibility that sulfur oxida. tion inereases anion eoneentration, thus holding eations in the soil solution and bringing about eonditions favorable to base exehange reaetions, will be developed later.

A review of the laterature emphasizes the need of further investigation as to the rôle of sulfur in the soil solution.

The writer wishes to acknowledge his indebtedness to Dr. W. F. Gerieke for helpful eounsel during the eourse of these investigations.

\section{SCOPE OF THE EXPERIMENTS}

The primary purpose of experiments reported herein has been to determine the effects of sulfur on soil solutions and their relation to sustained erop produetion. The study has ineluded the effeets of sulfur on soil reaction, liberation of bases, and eoneentration of sulfate and other anions, especially as related to the nutritive requirements of alfalfa at different growth periods and to sustained produetiveness of soils.

The main study has been chemieal, supported by some physiologieal experiments and eonfirming field trials, and has ineluded four lines of attaek, as follows: (1) effect of sulfur and sulfates on the soil solution; (2) effect of sulfur on the solutions of different soils; (3) determination of the minimum optimum eoncentration of sulfate for alfalfa by the water culture method; (4) eonfirmation of field-plat trials.

The soils employed and some of their eharaeteristics are given in table 1. 
RELATION OF REPLACEABLE BASES AND SULFOFICATION TO THE SOIL SOLUTION

The soil characteristics presented in table 1 indicate the amount of soil solution these soils can retain, their total sulfur content, sulfur oxidizing power, the sulfate content of their displaced soil solutions, the nature and amount of replaceable bases contained, and the response of these soils to sulfur treatment.

TABLE 1

SOME Characteristics of the Solls USED

\begin{tabular}{|c|c|c|c|c|c|c|c|}
\hline Soil series and type & $\begin{array}{c}\text { Usable } \\
\text { water } \\
\text { eapacity } \\
\text { (approx- } \\
\text { imate), } \\
\text { acre-ins. } \\
\text { per } \\
\text { acre-ft. }\end{array}$ & $\begin{array}{l}\text { Total } \\
\text { sulfur, } \\
\text { lbs, to } \\
2,000,000\end{array}$ & $\begin{array}{l}\text { Sulf ur } \\
\text { oxidized } \\
\text { in } 14 \\
\text { days, } \\
\text { per cent }\end{array}$ & $\begin{array}{l}\text { Sulfates } \\
\text { displaced } \\
\text { soil } \\
\text { solution, } \\
\text { p.p.m. }\end{array}$ & $\begin{array}{c}\text { Replace- } \\
\text { able } \\
\text { bases, } \\
\text { per cent } \\
\text { of soil } \\
\mathrm{Ca}, \mathrm{Mg} \text {, } \\
\mathrm{Na}, \mathrm{K}\end{array}$ & $\begin{array}{c}\text { Replace- } \\
\text { able } \\
\text { calcium } \\
\text { per cent } \\
\text { of soil }\end{array}$ & $\begin{array}{l}\text { Response } \\
\text { to sulfur } \\
\text { in field }\end{array}$ \\
\hline 1. Madera sand & $3 / 4 "$ & 821 & & 140 & .0613 & .0400 & Good \\
\hline 2. Umatilla med sand & $2 / 3 "$ & 240 & 36 & 32 & 1734 & .1248 & Slight \\
\hline 3. Catherine loam ... & $2 / 2^{\prime \prime}$ & & 17 & 464 & 7941 & .6512 & Fair \\
\hline 4. Yakima sandy loam. & $11 / 2^{\prime \prime}$ & & 15 & 64 & .2322 & .1419 & Good \\
\hline $\begin{array}{l}\text { 5. Deschutes sandy loam } \\
6 \text {. Willamette silty clay }\end{array}$ & $11 / 2^{\prime \prime}$ & 403 & 18 & 168 & 1967 & 1383 & Very good \\
\hline loam $\ldots \ldots \ldots \ldots$ & $2^{4 t}$ & 680 & 10 & $14^{*}$ & 4153 & .3654 & Slight \\
\hline 7. Carlton silt loam. & $13 / 4 "$ & 280 & 4 & $12^{*}$ & 2876 & .2600 & Fair \\
\hline 8. Antelope clay adobe. & $212^{\prime \prime}$ & 400 & 3 & $117 \dagger$ & 10816 & .8624 & Very marked \\
\hline
\end{tabular}

* Growing crop May 7.

† 2:1 extract.

The sulfofying power of a soil seems to have a closer relation to the sulfate content of the soil than does the total sulfur supply. Halversen and Bollen ${ }^{21}$ liave shown the relation of sulfur oxidizing power of soils to sulfate content. As sulfofication is largely a biological process, providing conditions most favorable for the organisms should aid in maintaining a favorable sulfate concentration in the soil solution. Application of manure with sulfur has appeared to be an effective aid to sulfofication in treated alkali land. ${ }^{30}$ Burd has recently reported data ${ }^{8}$ emphasizing the importance of biological activities in keeping up a favorable concentration of nutrient anions and the importance of supplying sufficient total anion concentration to hold favorable amounts of eations in the soil solution. Johnson ${ }^{31}$ seems to show that growing alfalfa may inerease the sulfate-supplying power of a soil. This may be due to plant removal of sulfate formed. The forms of sulfur in a soil may affect rate of sulfofication.

The total supply of replaceable bases and the proportion of univalent to multivalent bases adsorbed may indicate the power of 
reeovery of a soil solution after exhausting crops and the properties likely to be imparted due to base excliange reactions. Sulfur may oxidize and then unite with water to eause an increase in hydrogen ion coneentration in the soil solution. The presence of readily soluble compounds, such as calcium carbonate, under such a condition will favor solution, the rate of which will depend on the eoneentration of aeid present. Twentieth normal lychrochlorie acid in large quantity has been found to be capable of replaeing about all the replaeeable base held by the soil adsorbing eomplex where drainage is provided. ${ }^{17}$ When the concentration of hydrogen ion or otler eation is increased as a result of sulfur oxidation, base exchange may occur. This is sufficient to indicate the close and important relation of sulfur oxidation, solubility effects, and base exeluange reactions in the soil system to changes in its liquid phase. Where the supply of replaceable ealcium in table 1 is low and response from sulfur applications marked, it would seem to indicate that sulfur oxidation results in solubility effects.

Soils 2 and 6 (table 1 ) give little response to sulfur applications, and these soils oxidize sulfur rapidly. soil 2 is irrigated with water containing two or three poumds of sulfate sulfur per acre-foot. Soil 8 oxidizes sulfur slowly and gives marked response to sulfur applieations.

In order to learn the ehemieal effects of sulfur and sulfates on the soil solution twenty-eight two-gallon stoneware jars that had been eoated with valspar werc filled with sereened surface soil of Madera saud type which was known to give typical responsc to sulfur applications. These were divided into groups of four and treated witl different salts (table 2) at a rate sufficient to supply one hundred pounds of sulfur an acre. Three jars of each group were planted to Grimm alfalfa while the fourth was fallowed. Before the seedlings were one inch high, their number was reduced to ten uniform sized plants in each jar. The soil was maintained at abont optimum moisture eontent by frequent additions of distilled water and the fallows periodically sampled and sereened and their solutions displaced and analyzed, using methods deseribed by Burd. ${ }^{11}$ Displaeement of the soil solution is accomplished by packing the soil in brass tubes, arlding distilled water above as a displaeing medium, and then air pressure from the top.

Methods of analysis employed were, for the most part, those in use in the plant nutrition laboratories of the University of California 
and recently made available by Hibbard. ${ }^{25}$ The water culture technique employed has been described by Hoagland, ${ }^{28}$ Gericke, ${ }^{18}$ and Davis. ${ }^{14}$ Hydrogen ion concentration determinations of solution cultures were colorimetric and of displaced soil solutions were electrometric. Successive portions of displaced solutions were found to show fairly uniform electrical conductivity or specific resistance until dilution by the displacing medium began, at which point displacement was terminated, the dilute solution discarded, and the uniform solution saved and analyzed.

\section{CHEMIAL EXPERIMENTS}

\section{SULFUR AND SULFATES AND THE SOII SOLUTION}

TABLE 2

The treatments given to portions of soil are indicated in column 1, table 2. Sulfur was added at the rate of one lundred pounds per acre, while calcium oxide and sulfates were added in quantities contained in gypsum equivalent to one hundred pounds sulfur an acre.

The composition of the soil solutions displaced from treated and untreated fallow jars of Madera sand as determined in parts per million, after 6 weeks' and again after 12 weeks' incubation, is presented in table 2. Analyses are also given for the solution displaced from the original soil and for the two lots receiving heavy sulfur applications after 15 months.

The reaction of this soil on the untreated field plats was stightly alkaline and gave a pII value of 7.3. Soil from sulfured field plats was found to be exactly neutral. After 6 weeks' ineubation in the green house a very slight acidity had been developed in untreated, fallow jars, as shown later (table 6 ), perhaps owing to formation of carbonic acid from deeomposition of organic matter under the moist, warm conditions in the greenhouse. After 6 weeks' time the development of a slightly higher concentration of hydrogen ions was observed in soils that had been treated with sulfur or with certain sulfates. The concentration of sulfate ion in the solutions displaced in such cases was found to have increased. After 12 weeks' incubation the hydrogen ion eoncentration had inereased with certain sulfate treatments, and the heavy sulfur application resulted in hydrogen ion concentrations that were unfavorably high for growth. This high acidity still prevailed after 15 months. In the cropped series definite 
acidity developed and growth appeared to maintain a hydrogen ion concentration of about pH 6.0. Reaction might be inodified by decomposition of organic matter, excretions by roots, formation of sulfuric acid in sulfur treated pots, as by hydrolysis, and selective absorption of cations, added in certain salts such as sulfate of ammonia.

\section{TABLE 2}

EFFect of Sulfur and Sulfate on the Soll Solution

Analysis reduced to 10 per cent moisture (wet weight).

\begin{tabular}{l|c|c|c|c|c|c|c}
\hline \hline \multicolumn{1}{c|}{ Initial soils } & Dec. & \multicolumn{5}{|c}{ Parts per million soil solution } \\
\cline { 1 - 5 } Treatment, pounds per acre & $\mathrm{pH}$ & $\mathrm{NO}_{3}$ & $\mathrm{SO}$ & $\mathrm{PO}_{4}$ & $\mathrm{Ca}$ & $\mathrm{K}$ & $\mathrm{Mg}$ \\
\hline Untreated plot & 7.3 & 47 & 140 & 4.5 & 119 & 57 & 129 \\
Sulfured plot & 7.0 & 25 & 194 & 35 & 146 & 83 & 78
\end{tabular}

Analysis of fallows (after six weeks incubation)

\begin{tabular}{|c|c|c|c|c|c|c|c|}
\hline $\mathbf{X}$ untreated ....... & 62 & 116 & 253 & 40 & 144 & 98 & 119 \\
\hline Sulfur, $100 \mathrm{Ib} . . .$. & 61 & 161 & 369 & 35 & 203 & 125 & 221 \\
\hline $\mathrm{CaO} \ldots \ldots \ldots \ldots$. & 6.5 & 127 & 195 & 60 & 142 & 88 & 95 \\
\hline s and $\mathrm{CaO}$ & 6.3 & 156 & 256 & 50 & 196 & 105 & 156 \\
\hline $\mathrm{K}_{2} \mathrm{SO}_{4}$ & 6.1 & 157 & 294 & 30 & 116 & 172 & 113 \\
\hline $\mathrm{CaSO}_{4} \ldots .$. & 6.3 & 120 & 247 & 3.5 & 135 & 112 & 90 \\
\hline $\mathbf{X}$ & 67 & 70 & 161 & 40 & 172 & 60 & 91 \\
\hline$\left(\mathrm{NH}_{4}\right)_{2} \mathrm{SO}_{4} \ldots$. & 54 & 150 & 205 & 40 & 227 & 63 & 121 \\
\hline $\mathrm{MgSO}_{4} \ldots \ldots \ldots$ & 5.9 & 53 & 235 & 4.5 & 294 & 63 & 196 \\
\hline Displaced soil..... & 65 & 30 & 153 & 40 & 160 & 27 & 98 \\
\hline$S-200 \ldots \ldots \ldots \ldots \ldots \ldots$ & 58 & 38 & 284 & 50 & 327 & 125 & 119 \\
\hline$S-500 \ldots \ldots$ & 5.9 & 21 & 509 & 35 & $34 ?$ & 133 & 102 \\
\hline
\end{tabular}

Second analysis (after twelre weeks)

\begin{tabular}{|c|c|c|c|c|c|c|c|}
\hline $\mathrm{X}$ & 61 & 124 & 261 & 30 & 207 & 107 & 160 \\
\hline s ... & 63 & 100 & 341 & 5.0 & 382 & 72 & 131 \\
\hline $\mathrm{CaO}$ & 67 & 102 & 204 & 5.0 & 324 & 127 & 118 \\
\hline $\mathrm{CaO}$ and is & 67 & 77 & 322 & 50 & 356 & 120 & 144 \\
\hline $\mathrm{K}_{2} \mathrm{SO}_{4}$ & 65 & 84 & 282 & 40 & 361 & 165 & 165 \\
\hline $\mathrm{CaSO}_{4} \ldots$ & 66 & 82 & 224 & 40 & 351 & 84 & 79 \\
\hline $\mathrm{X}$ & 58 & 87 & 190 & 40 & 139 & 47 & 139 \\
\hline$\left(\mathrm{NH}_{4}\right)_{2} \mathrm{SO}_{4} \ldots$ & 56 & 176 & 258 & 5.0 & 326 & 57 & 128 \\
\hline $\mathrm{MgSO}_{4} \ldots$. & 5.6 & 79 & 241 & 40 & 268 & 64 & 183 \\
\hline Displaced soil & 64 & 88 & 219 & 3.5 & 124 & 32 & 148 \\
\hline$S-200 \ldots \ldots \ldots$ & 48 & 47 & 376 & 240 & 376 & 135 & 157 \\
\hline$s-500 \ldots . . .$. & 44 & 37 & . & 520 & & 156 & 171 \\
\hline
\end{tabular}

Third analysis (after fifteen months)

\begin{tabular}{|c|c|c|c|c|c|c|c|}
\hline $\mathrm{X}$ & 7.7 & 44 & 94 & 2.0 & 79 & 70 & \\
\hline 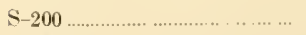 & 38 & 24 & 672 & 1.0 & 152 & 174 & \\
\hline 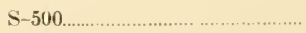 & 36 & 1 & 1510 & 15.0 & 171 & 319 & \\
\hline
\end{tabular}


The nitrate in field plats, treated with 200 pounds of sulfur per acre about a year previous to sampling, was lower than in the adjacent untreated plat. After incubation for 6 weeks there was a tendency toward accumulation of nitrates except where unfavorable acidity had developed. After 12 wecks, high acidity developed in heavily sulfured jars, which made conditions unfavorable for nitrification and depressed the supply of nitrate to or below that of the untreated soil. A large portion of the nitrogen in the ammonium sulfate applied appeared later as nitrate.

An initial supply of 140 parts per million of sulfate was found in the soil solution. Since this soil will retain about 10 per cent useable moisture between the wilting point and the excess point, this represents 14 parts pel million sulfate for the whole system. Sulfur in the field trial inereased the sulfate content to 194 parts per million. Madera sand appeared to have good sulfofying power, cren without sulfur additions. Addition of sulfur and sulfate substantially increased the sulfate content of the soil solution in six weeks. Adding calcium oxide with sulfur appeared to retard, rather than to encourage, sulfofication. Sulfofication appeared to be somewhat proportional to the amount of sulfur applied, for in subsequent determinations gains in sulfate eoncentration were found. Small differences were found from the application of various sulfates.

The amount of soluble phosphate first seems to increase, then to decrease, after sulfur treatment. There appears to be a little depression in the amount of phosphate in the solution after sulfur applied has brought eonsiderable calcium into solution. With heavy sulfur applications, marked inerease in acidity and increase in the amount of phosphate were found in the soil solution after 12 wecks' incubation. Increase in solubility of bases sueh as calcium, iron, or aluminum appears to have resulted in precipitation of phosphate before 15 months passed.

Calcium was found to come into solution strikingly as a result of sulfur or sulfate applications. Nearly thrce times as mueh calcium was found in the soil solution following heary applications of sulfur. Sulfur appears to have modified the soil solution with respect to calcium mole than with any other ion.

Potassium was brought into solution in the soil to the extent that the supply in solution was almost doubled by heavy applieations of sulfur. Part of the potassium, when applied as potassium sulfate, appeared to be fixed by exchange reaction with other bases which 
were brought into solution. Heary applieation of sulfur resulted in a large inerease in potassium ion in the soil solution after 15 months. Either potassium-bearing compounds were slowly dissolved or the calcium had participated in a base exchange with the potassium in the solid phase.

Magnesium ion has a tendency to increase in concentration in the soil solution owing to sulfur additions and possibly also to base exclange reations following an increase in total concentration of the soil solution.

The analyses in general indicate that a very important function of sulfate is that of bringing in and holding bases in solution. It also appears to increase the soil acidity with a resulting increase in arailability of phosplate. The phosphate, however, may tend to disappear if the soil is well supplied with bases, such as calcium, which may reaet on the ealcium and cause precipitation of phosphate from the soil solution. This reciprocal relation of soluble calcium relative to phosphate has been noted by Burd. ${ }^{9}$

\section{SULFUR AND SOIL SOLUTIONS OF DIFFERENT SOILS \\ TABLE 3}

Samples of typieal Oregon soils were eolleeted from old sulfur experiment fields, including soil from both sulfured and unsulfured plats, that had been in experiments for as long as ten years and had received sulfur generally at the rate of one hundred pounds per acre every three or four years. These samples were screened and brought to optimum moisture content, allowed to stand so that equilibrium would be established between the solid and liquid phases of the system, and the displaced soil solutions recovered and analyzed.

Results are given in table 3 and show that sulfur applications increase acidity in all cases, and usually more than $0.5 \mathrm{pH}$. There was a noticeable difference in the buffer value of various soils used. The Catherine loam did not resist ehange in reaction well and beeane unfavorably aciel. The nitrate eontent of these solutions was not greatly nodified, but gave evidence of being depressed in certain cases from sulfur applications on aeid soils, as shown in the ease of Catherine loam.

The sulfate content of Willamette and Carlton soils was found to be very low. Samples were taken from these soils on May $T$ following a cool spring. whieh would be unfavorable to sulfur oxidation, and from plats supporting winter grain that had attained 5 to 9 inches 
height. Both these humid soils are subject to leacling in winter. Sulfofication is rapid under laboratory conditions in the Willamette soil and little erop increase results from sulfur applications thereto, while Carlton soil is lower in total sulfur and sulfate and responds to sulfur applications. Sulfur substantially increased the sulfate content of all soil solutions. There was a tendency for sulfur to increase the calcium content of the soil solution, and also the potassium content.

TABLE 3

EFFect of Sulfur on Soll Solutions

Soils displaced May, 1925, reduced to comparative moisture basis.

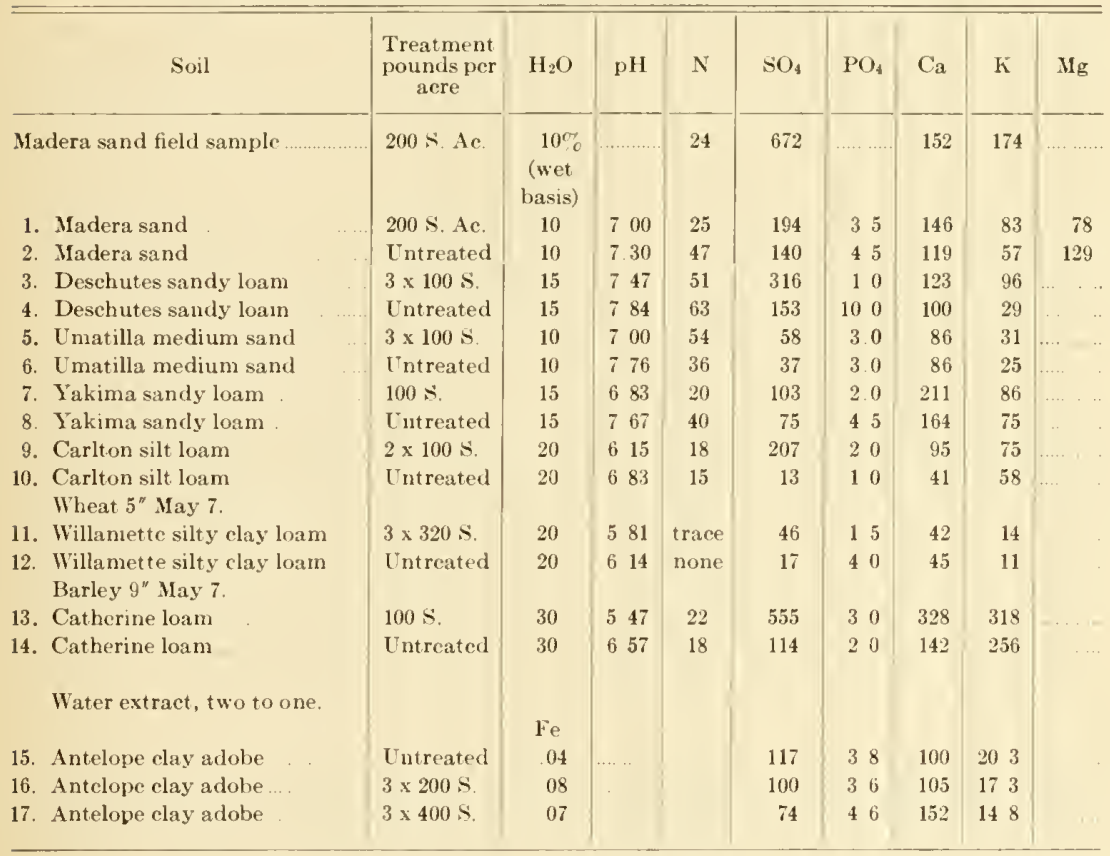

Willamette silty clay loam and Carlton silt loam are acid soils, the latter occurring in the low foothills of the Willamette Valley. The Willamette soil from the old valley filling contains a fair total amount of sulfur, and this soil has a high sulfofying power and good supply of organic matter. It gives only slight response to sulfur applications. Carlton and other "redhill" soils are low in total sulfur and in soluble sulfate and give moderate response to sulfur treatment. They are also low in soluble calcium, and in some instances the soluble potassium is low. Sulfur may help to bring bases into solution in these acid soils, but calcium sulfate may be more safely used. 
Umatilla medium sand receives from two to three pounds of sulfur in each acre foot of irrigation water and requires at least five acre-feet of water a season. This soil is rather low in replaceable bases and does not afford much opportunity for base excluange. It gives slight response to sulfur applications. On the finer soils in that region a moderate increase in alfalfa yield is secured from sulfur applications.

Catherine loam has given more profitable returns from ealcium sulfate than from sulfur. The reaction of this soil is already slightly acid and sulfur may develop an unfavorably acid condition. This was formerly wild meadow land.

Yakima sandy loam and Deschutes sandy loam are arid soils of nearly neutral reaction with large total supplies of ealeium and having only moderate amounts of potassium ion in their soil solutions. The former is typical of the main soil area of Klamath Project. Potassium salts pay when applicd to Deschutes sandy loam in which potatoes are growing, and sulfur appears to bring treble the amount of potassium into the soil solution in this soil. The alfalfa crop in this section when soil-treated with sulfur develops an especially rich green color.

The samples of Antelope clay adobe used in these experiments come from the sulfur fertilized plats established by F. C. Reimer north of Medford and are too heavy for displacement, so water extracts were made. The amount of iron in solution was doubled by sulfur applications and there was some increase in calcium ion in solution. Iron pyrite on this land has given as good increase in alfalfa yield as sulfur, after time was allowed for oxidation of the pyrite. Ferrous sulfate has given the best yields in plat trials at this experiment field. ${ }^{50}$

After the analyses above given were completed, ferrie chloride was sprayed on two plats of alfalfa previously unfertilized and a vigorous growth resulted, showing all the visible results commonly secured from sulfur on this field. There is a possibility of iron participating in a base excliange but that does not secm to have been an important factor here. Iron sulfate has been suceessfully used to orercome chlorosis in fruit trees where applied at the tree roots in this heary soil.

The chief effect of sulfur may depend considerably on the characteristies of the partieular soil at hand and its reaction, plysical eondition, ehemical composition, or micro-organisms present. On arid soils of slightly alkaline reaction sulfur may improve the reaction of 
the soil solution for alfalfa. This may inerease the solubility of iron in the soil solution and favor the development of chlorophyll. It may also faror the absorption of anions, such as nitrates, by plants. A better supply of caleium, as well as sulfate, is often provided by an application of sulfur.

\section{SULFUR AND ALFALFA YIELD WTTH SOILS IN JARS}

Four portions of each of thesc soils were arranged in one-gallon jars, two being treated with sulfur at the rate of one hundred pounds an acre, the others untreated. One treated and one untreated jar containing soil of each type were then planted to alfalfa for culture tests and for displacement and analysis, if needed, to check against field plat samples.

The increase in yield of alfalfa secured in these jars as a result of sulfur treatment ranged from 7 per cent to 54 per cent. Umatilla sand appeared to give greate" response to this treatment, in the jars and irrigated with distilled water, than under field conditions where large amounts of irrigation water contributed a substantial part of sulfur needed by the alfalfa. Ferrie chloride was found to be about : effeetive as sulfur on Antelope clay adobe, for increasing alfalfa vield in jars, which is further evidence that an important effect of sulfur on this soil is to improve availability of iron and overcome chlorosis in alfalfa grown in it.

A preliminary experiment was conducted with young alfalfa transplanted from Madera sand soil from near Delli, California. These plants had grown through the summer season on soil recciving no sulfur. Three two-gallon jars were untreated, a seeond lot of three received sulfur, a third lot, repreeipitated calcium carbonate and sulfur, a fourth received, sulfur as caleium sulfate, and the fifth lot reeeived potassium sulfate at a rate that would supply one liundred pounds of sulfur to the acre. The plants were set out December 29, 1923. Cuttings were made when the growth bloomed freely, February 29, May 5, and May 27. One jar of each lot was not harvested at the second cutting but was left for seed. The effeet of sulfur was to faror seed formation. Sulfur or sulfates increased the height, vigor, and yield of alfalfa in this trial 20 to 40 per cent.

Sulfur reduced the water requirement about one-third, as expressed in units of water per unit of dry matter. 
Thirty-six two-gallon stoneware pots, paralleling the fallow jars used for analyses, were planted to Grimm alfalfa, thinned to ten plants per jar and four months' growth harvested in one cutting May 27,1924 . All the sulfates were applicd in amounts needed to provide one lundred pounds per acre of sulfur and gave similar increases in yield. The jars receiving potassium sulfate attained the maximum height. Moderate increases over the untreated pots rere secured with caleium and with sulfur used singly or combined. The increased efficiency of water consumed by this growth in treated jars was reflected in a lower water requirement per unit dry matter. A more favorable concentration of soil nutrients or better balance in the solution should lead to a lower transpiration and therefore a lower water requirement, unless other conditions cause small yield of dry matter.

HYDROGEN ION CONCENTRATION IN CROPPED AND FALLOW SOIL, POTS

The lydrogen ion determinations were made about every two weeks for all soil in jars. Colorimetric tests were made promptly, after sampling, with fresh color standards ehecked with the lyodrogen electrode.

Decomposition of organie matter on untreated fallow pots seems to have brought the reaction down from pH 6.9 to about 6.2. Calcium carbonate tended to maintain a more nearly neutral reaction, while heary application of sulfate dereloped an unfavorably atid condition.

cropped pots when untreated developed a slight acidity and maintained a pII of about 6.0. There was a somewhat more uniform reaction in eropped pots due perhaps to the tendeney of plants to maintain a favorable reaction. Results strongly indieate that a slightly acid reaction is brought about by $\mathrm{CO}_{2}$ evolved by growing roots in cropped pots or from decomposition of organic matter in fallows forming $\mathrm{IICO} \mathrm{C}_{3}$ as suggested by Hoagland..2 They also indieate that a slightly aeid reaction is most favorable for alfalta growth in soil and that moderate applieations of sulfur may improve the reaction of basic or slightly alkaline arid soils for alfalfa nutrition. 


\section{PHYSIOLOGICAL EXPERIMENTS}

In order to test the adequacy, for alfalfa growth, of sulfate eoneentrations found in soil solutions, some supplementary water culture experiments were undertaken. It was hoped that this would shed further light on the sulfate need of alfalfa, the form in whieh sulfate is best obtained from the soil solution, the part of the growth period when sulfate is most needed, the crop-produeing power of limited amounts of sulfate, and especially the concentration of sulfate needed for best growth. For this work fruit jars were used and the seedlings supported on flat perforated eorks. Molal solutions were prepared of di-potassium aeid phosphate, mono-potassinm aeid phosphate, ealeimm nitrate, and magnesimm sulfate. From these stoek solutions a culture solution was made up to an osmotic eoncentration equal to approximately 1 atmosphere pressure and a $\mathrm{pH}$ vahe of about 6.0. Sulfur-free eulture solutions were provided by substituting ealeium nitrate for magnesium sulfate, and limited amounts of sulfate were added in eertain experiments from a saturated solution of ealeium sulfate to provide the number of parts per million of sulfate desired. I fresh solution of iron-tartrate was used for supplying soluble iron. In these experiments records were kept of the height and vigor of plants, the amount of transpiration. and the reaetion to eulture solutions. The reaction tests were made almost daily where there was a tendency to deviate from the optimum range.

\section{Preliminary S'tudies}

TABLES 4 TO 8

Two-year-old alfalfa plants were seeured from sulfured and unsulfured field plats near Delhi, where crops grown on Madera sand had shown typieal response to sulfur. The erowns of plants grown on sulfured fields were mueh larger than those of the same age from the unsulfured plats. The eolor of foliage on sulfured land was a dark green, the plants presenting a marked eontrast to the rather ehlorotie, unthrifty plants from the mnsulfured plats. Sulfur in this field trial had doubled the yield of alfalfa. The plants were washed 
free of soil, dried on a blotter, and their individual weights determined. There had been some root pruning so the tops were elipped baek elose to the erowns. The plants recovered promptly from transplanting when plaeed in the nutrient solution.

TABLE 4

Alfalfa Transplanted From Sulfur-Treatfd LaNd

Mean yield in grams. Dry matter (3 euttings) from single two-year-old plants.

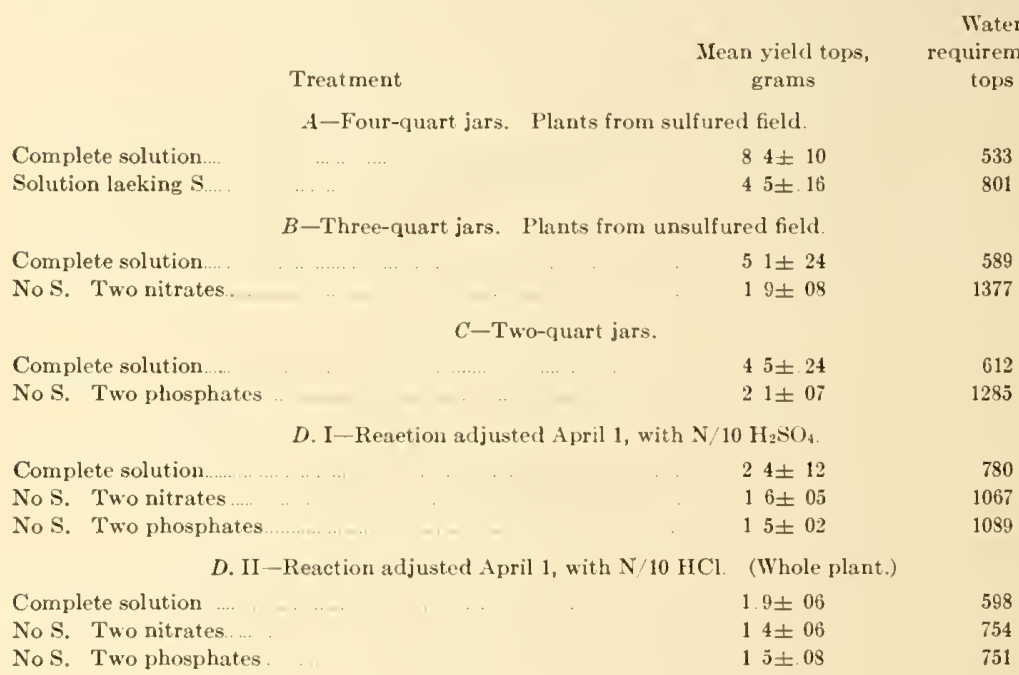

A trial was made with twelve plants from the unsulfured field plat, the plants being divided evenly into two lots aeeording to weight. Six plants were placed on four-quart jars eontaining complete eulture solutions and six others on solutions lacking sulfur. In two weeks a difference in the appearanee of the plants was moticeable. The plants provided with sulfate developed a better green eolor and made over twice the growtl during the first two months eompared with those grown in the sulfur-free solution. The plants eame into bloom and were ent January 29, April 23, and May 27, 1924. The yields are presented in table 4 , section 1 . Approximately twiee the yield of dry matter was secured from plants grown on solutions provided with sulfate. These plants made nearly twice as efficient use of rater consumed for each unit of dry matter produced as did the sulfur-free series.

$A$ second lot of plants were set on three-quart jars and treated as in the above experiment, except that the sulfur-free solution ineluded two nitrate salts instead of two phosphate salts as in the above 


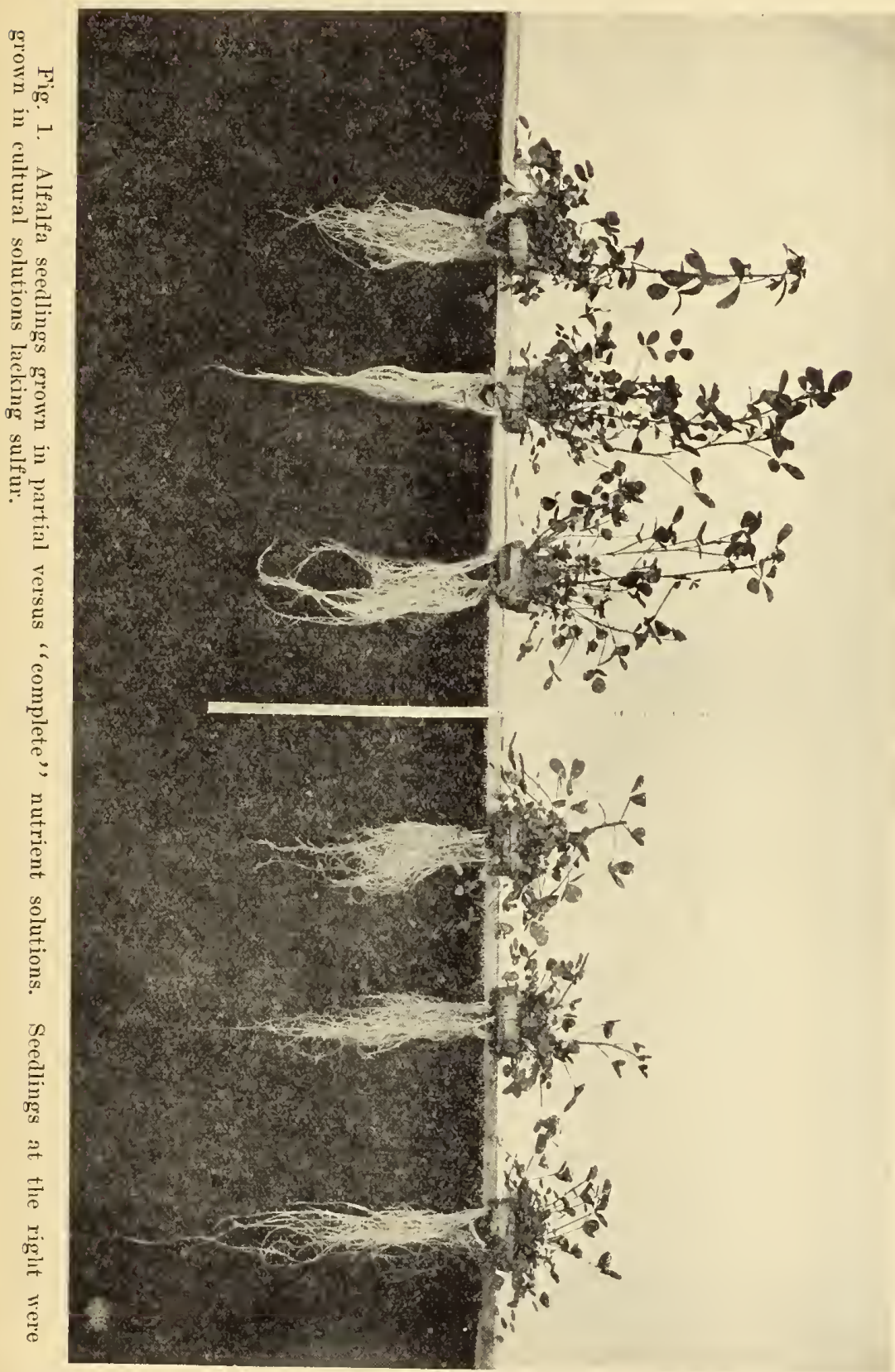


trial. The presence of two nitrate salts, or a larger supply of nitrates, was assoeiated with greater rields relative to untreated plants than was secured in the above experiment (table $4, B$ ). These transplants were one year old and sulfur about trebled the yield, resulting in a transpiration requirement of about three-sevenths of that from the plants grown in sulfate-free solutions.

A third lot of transplants from the unsulfured alfalfa plats were divided into lots of six and plaeed on two-quart jars, one-half being provided with a complete enlture solution and the others with a solution lacking sulfatc. The yields of these plats are presented in seetion $C$ of table 4 . Where sulfate was provided the plants ontgrew their ehlorotie appearance in two to thrce weeks' time, indicating that lack of sulfate was the eause of their devitalized eondition. The total vield for plants provided with sulfate was more than twiee that from the sulfur-free series for three euttings, and eonsumed less than half the amount of water per unit of dry matter prodneed.

A fourth lot of transplants two months old was secured without root injury and set on three dozen, one-quart eulture jars. One dozen of these jars were provided with a eomplete nutrient solution; a second dozen were provided with a water eulture solution lacking sulfate and eontaining two nitrate salts; and the third dozen were provided with nutrients using two phosphate salts. When these plants were six weeks old they developed a ellorotic appearance, and at that time half of the dozen plants in the sulfur-free solution were brought to a favorable reaction by the use of $\mathrm{N} 10$ sulfuric aeid. To six other cultures $N 10$ hydroehlorie was applied to produee a farorable reaetion. Results of this trial, table 4 , section $1 \%$, show a marked inerease in vield where sulfate was included. Applying a limited quantity of sulfate, when plants had heen grown for six weeks on enlture solutions, prodneed more improvement than ean be credited to improved reaction alone. In all these trials the water eonsumption was greatly inereased where sulfur was lacking. In three days' time the sulfate added in acid eaused a dark green color of the foliage, which was notieeable until the plants were larvested a month later. 'This difference is indieated in figure 3 . 


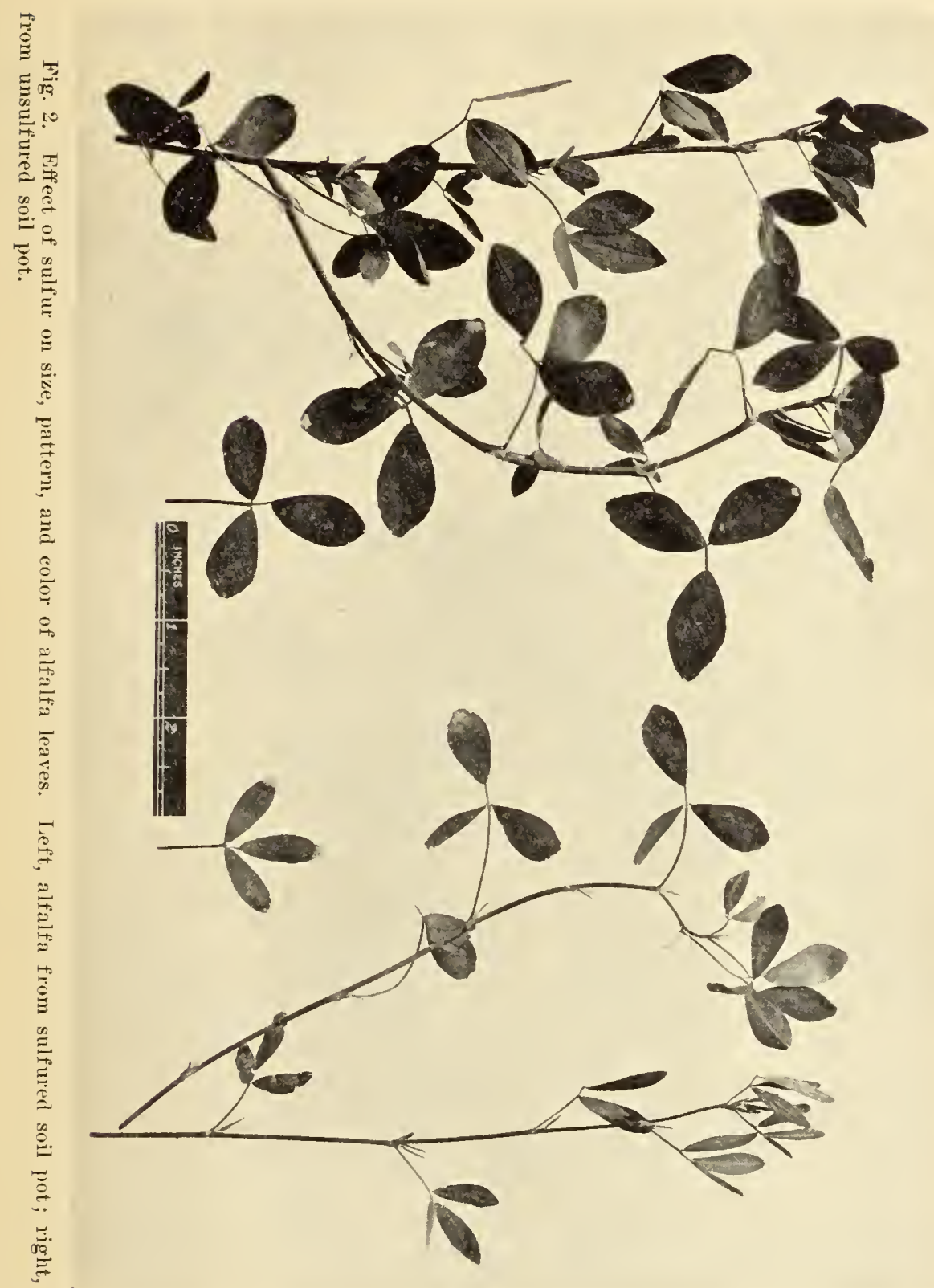




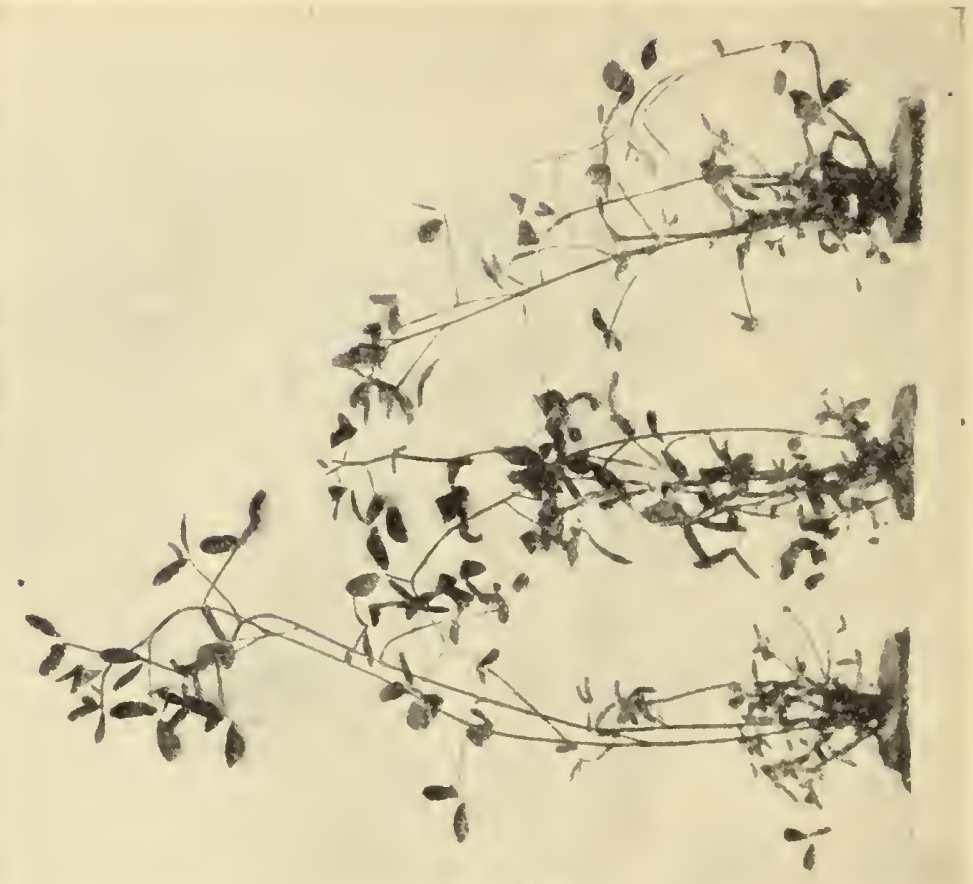

ב⿱

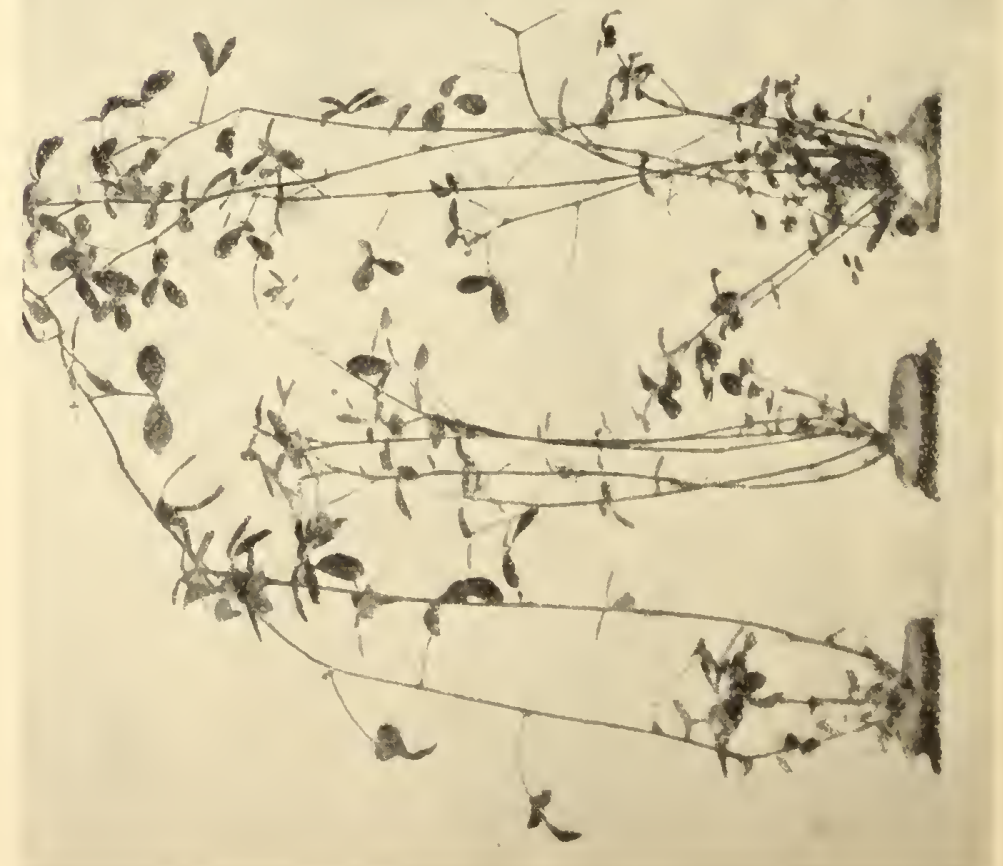




\section{SULFUR AND CHLOROPHYLL}

Chlorophyll determinations, following methods described by Willstätter, with the whole top growth from sulfured and unsulfured alfalfa in soil pot trials, yielded 12 per cent more chlorophyll where sulfur was applied. Alfalfa leaves collected from sulfured and unsulfured field plats showed an increase of 18 per cent in chlorophyll content. The effect of sulfur in increasing width, size, and color of alfalfa leares is indicated in figure 2. Lack of sulfur resulted in a lack of rich green color and lack of vigor. Data in table 3 show that sulfur application increased the iron content of the water extract from Antelope clay adobe and this iron is known to play an important rôle in chlorophyll synthesis. Sulfuric acid was also found to restore color better than hydrochloric acid when used to adjust reaction in culture solutions.

\section{WATER CULTURE EXPERIMENTS WITH SEEDLINGS}

TABLe $5, A$

To check the plan of providing sulfate to secdlings in partial culture solutions two days in six, three series of cultures were provided. In the first, plants were exposed to calcium sulfate one day in five; in the second, two days in six; and in the third, four days in eight. The remainder of the period the plants grew on culture solutions lacking sulfur. During the first two months of the experiment the best growth was obtained with plants exposed to calcium sulfate two days in six. In the latter part of the growth period the plants exposed to sulfate only one day in five forged ahead and gave definitely better total yields both of total and marketable dry matter, indicating that extra sulfur was most helpful in the early part of the growth period and perhaps undesirable later. Figure 6 shows typical plants of each scries after three months' growth. There was little difference in the yields of the plants exposed two days, compared to those exposed four days to sulfate solution, as shown in section $A$ of table 5. There was a marked difference in appearance of plants with and without sulfur in this and other trials, as shown in figure 7 . 
HOW DOES SULFUR GO FNTO THE PLANT:

\section{TABLE $5, B$}

Sixteen series of six enltures each containing three Grimm alfalfa seedlings per culture were employed in an experiment, which covered a growing period of 110 days. Plants were grown on culture solutions lacking sulfur four days in six and on various partial eulture solutions containing different sulfates two days in six. Solutions were changed

\section{TABLE 5}

How Does Sulfur Go Into the Plant?

Alfalfa yield in grams. Dry matter. May 26, 1924.

(Grown on sulfur-free culture solutions and transferred to solutions containing sulfate at regular intervals.)

A.

\section{Treatment}

Complete culture solution, unchanged

Complete cult ure solution, changed monthly

S-free solution, unchanged

S-free solution, changed monthly

S-free solution 4 days; then $\mathrm{CaSO}_{4} 1$ day

S-free solution 4 days; then $\mathrm{CasO}_{4} 2$ days

S-free solution 4 days; then $\mathrm{CasO}_{4} 4$ days

$B$.

S-free solution 4 days; then $\left(\mathrm{NH}_{4}\right)_{2} \mathrm{SO}_{4} 2$ days

s-free solution 4 days; then $\mathrm{MgSO}_{4} 2$ day's

S-free solution 4 days; then $\mathrm{K}_{2} \mathrm{SO}_{4} 2$ days

$\mathrm{S}$-free solution 4 days; then $\mathrm{Ca}, \mathrm{NO}_{3}, \mathrm{NO}_{4}$ and $\mathrm{PO}_{4} 2$ days

S-free solution 4 days; then $\mathrm{Mg}, \mathrm{NO}_{3}, \mathrm{SO}_{4}$ and $\mathrm{PO}_{4} 2$ days

S-free solution 4 days; then $\mathrm{K}, \mathrm{NO}_{3}, \mathrm{SO}_{4}$ and $\mathrm{PO}_{4} 2$ days

S-free solution 4 days; then $\mathrm{Ca}, \mathrm{NO}_{3}$ and $\mathrm{sO}+2$ days

s-free solution 4 days; then $\mathbf{M g}, \mathrm{NO}_{3}$ and $\mathrm{SO}_{4} 2$ days

$\mathrm{S}$-f ree solution 4 days; then $\mathrm{K}, \mathrm{NO}_{3}$ and $\mathrm{SO}_{4} 2$ days

\begin{tabular}{|c|c|c|}
\hline \multicolumn{2}{|c|}{ Mean yield } & \multirow[b]{2}{*}{$\begin{array}{c}\text { Water } \\
\text { requirement } \\
\text { tops }\end{array}$} \\
\hline $\begin{array}{l}\text { Whole } \\
\text { culture } \\
3 \text { plants }\end{array}$ & Tops & \\
\hline 3. 1 & $22 \pm .08$ & 855 \\
\hline 3.9 & $24 \pm 15$ & 867 \\
\hline 38 & $22 \pm 16$ & 851 \\
\hline 41 & $26 \pm 10$ & 712 \\
\hline 57 & $39 \pm 23$ & 569 \\
\hline 42 & $27 \pm 14$ & 790 \\
\hline 45 & $29 \pm 23$ & 651 \\
\hline
\end{tabular}

C. Solutions frce of $\mathrm{K}$ and $\mathrm{SO}_{4} \mathrm{vs}$. - (Cation supplied only 2 days in 6 and with $\mathrm{SO}_{4}$ )

S-free solution 4 days; then $\mathrm{CaNO}_{4} 2$ days

S-free solution 4 day's; then $\mathrm{K}_{2} \mathrm{SO}_{4} 2$ days.

S-free solution 4 days; then $\left(\mathrm{NH}_{4}\right)_{2} \mathrm{SO}_{4} 2$ days

Complete solution

S-free solution 4 days; then $\left(\mathrm{NH}_{4}\right)_{2} \mathrm{SO}_{4}$ (grain) 2 days

Displaced soil solution ( 6 weeks' grow th)

Displaced soil solution plus $\mathrm{K}_{2} \mathrm{FO}_{4}$

$\begin{array}{rrrr}36 & 2.7 \pm 21 & 725 \\ 18 & 12 \pm 10 & 796 \\ 53 & 36 \pm 18 & 635 \\ 55 & 36 \pm 13 & 639 \\ 9 & 28 \pm 69 & 1875 \\ 46 & 33 \pm 23 & 699 \\ 46 & 33 \pm 06 & 691 \\ 13 & 10 \pm 16 & 1149 \\ 3.6 & 3.3 \pm 21 & 638\end{array}$

frequently during the latter part of the growth period to avoid contamination by moving the plants from the sulfur-free nutrient solution to the companion solutions containing different forms of sulfate. The plant roots were washed by standing them in two-gallon jars of tap water for twenty or thirty minutes and then rinsing in distilled water before transferring from one partial solution to the other. An extra series of stationary eontrols having sulfur, and one lacking sulfur, 


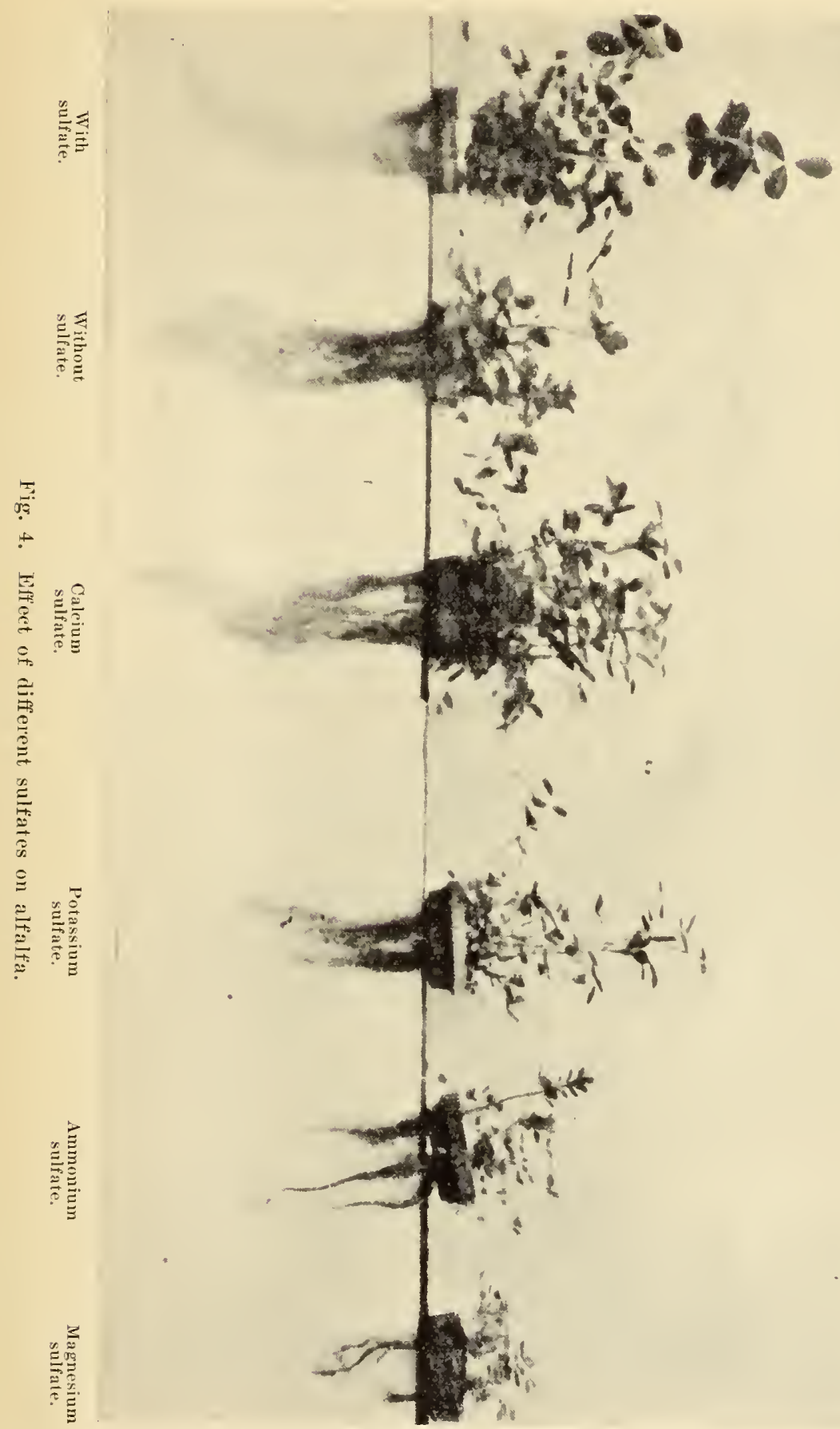


were provided to test the effect of changing the nutrient solutions monthly. Changing the solution showed a little advantage, as did changing the plants. This was probably duc to improved aeration.

Two days in six, series 8 to 12 received sulfate in single salt solution as calcium sulfate, potassium sulfate, ammonium sulfate, or magnesium sulfate, respectively. During the first two months of this experiment plants receiving sulfate in the form of ealcium sulfate were definitely the better plants. During the last four or five weeks of the experiment these were overtaken by the potassinm sulfate series, the yield of which was slightly greater. The yield with ammonium sulfate was about four-fifths of that with the calcium sulfate, while the magnesium sulfate series yielded only about two-fifths as much as the calcium sulfate series.

Series 12 to 14 were provided in which the sulfate-bearing solution received nitrate, phosphate, and sulfate salts of the base under consideration. Under this condition calcium salts produced one-eighth more total dry matter than the potassium salts. The yield with magnesium sulfate was very low.

In series 15 to 17 the cations were supplied in both nitrate and sulfate forms. There was no significant difference in the rield obtained with potassium from that obtained with calcium sulfate.

In all trials, solutions containing magnesium salt gave very poor results. The reaction was difficult to control in the case of magnesium salt solutions, and even with reaction controlled there appeared to be magnesinm toxicity. During the first two months of the growth period, calciun sulfate appeared to be definitely the best form of sulfur for the alfalfa plants. For typical plants, the relative growth for different treatments is shown photographically in figure 4.

During the latter part of the growth period potassium sulfate showed advantage in certain eases.

\section{CALCLUM SULFATE VERSUS POTASSIUM SULFATE TABLe 5, $C$}

An experincut was aranged to compare further the value of calcium sulfate with that of potassium sulfate. In this experiment the main solntion was deprived of both sulfate and the cation conecrned, so that it could be obtained only during the two days out of six when the roots were in the partial untrient solution containing sulfate. Thus calcium, potassium, or magnesimm was held out of the main solution and applied only as sulfates in the partial nutrient 


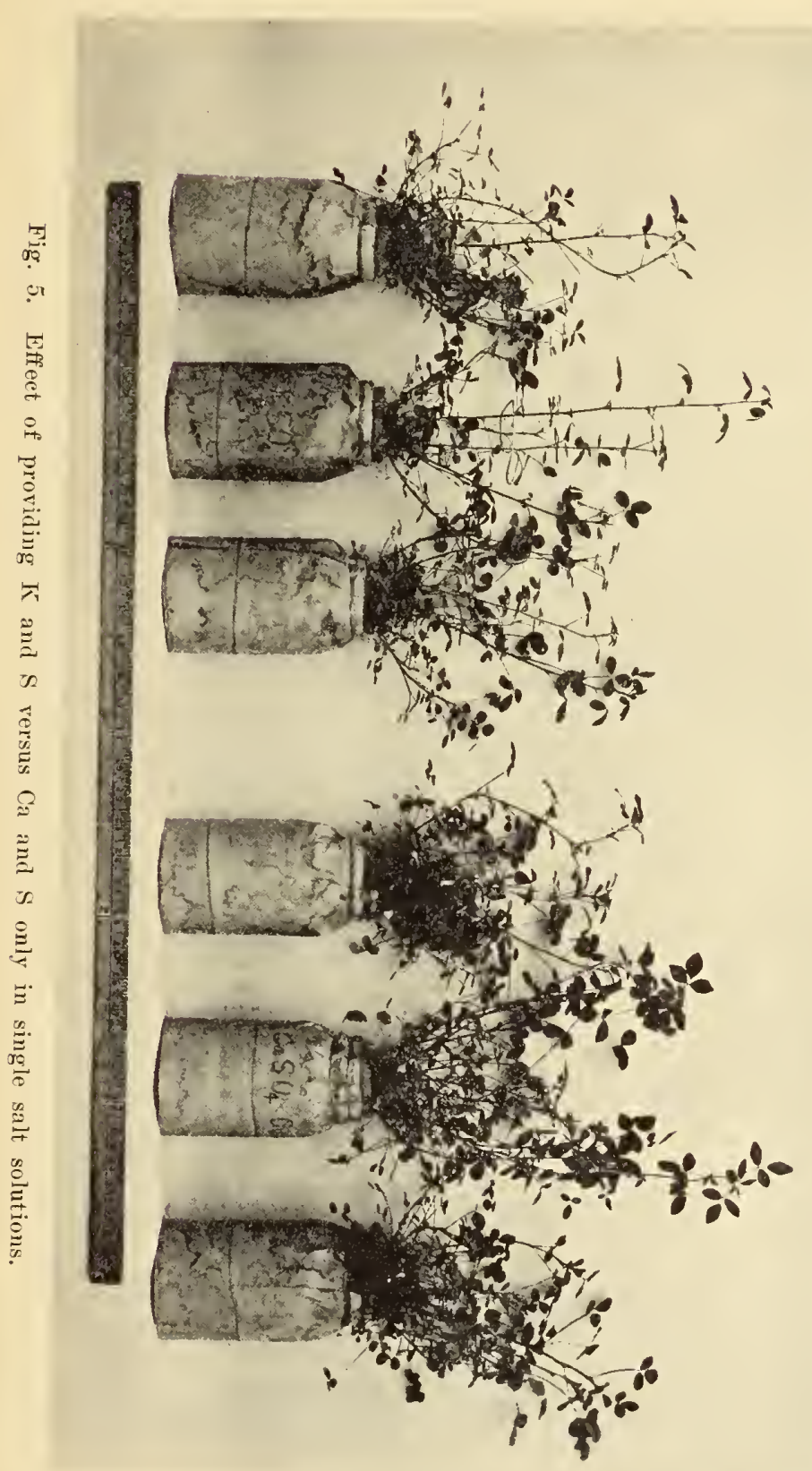


solutions to which plants were transferred two days in six. Also nitrogen, as well as sulfur, was liept out of a certain main solution, being provided only two days in six as ammonium sulfate. In this experiment potassium sulfate gave only about three-fifths the yield of tops and of total dry matter as was seeured with caleium sulfate. In this trial nitrogen and potassium were not present at one time, and the calcium sulfate excelled during nearly all of the growtl period, as shown in figure 5 . During the period when the plants were nine to ten weeks old, the potassium sulfate series and ealcium sulfate series were nearly equal in size.

In connection with the value of potassium sulfate relative to calcium sulfate, it should be noted that calcium encouraged much branching of roots and a bushy top growth, or cell division; whereas potassium produced eell elongation and seemed more important at that period of growth when the alfalfa was making its maximum increase in height. The ash of alfalfa contains about 16.25 per cent calcium and 24.7 per cent potassium and the oven dry alfalfa, 1.26 per cent calcium as against $1.87 \mathrm{per}^{\mathrm{cent}}$ for potassium. ${ }^{32}$ As shown by Gericke $^{18}$ potassium is best supplied to plants in assoeiation with nitrate, and this was rerified in the eourse of these experiments.

\section{COMPLETE NUTRIENT SOLUTION VERSLS DISPLACED SOIL} SOLUTION

TABLE $\tilde{j}, \mathrm{C}$

In conncetion with these experiments, threc series of 400 ce. bottles were provided, set with two alfalfa seedlings to each eulture. One set was filled with a complete nutrient solution, the second with the natural soil solution displaced from the Delhi soil, and the third series with displaced solution reinforced with sulfate applied as potassium sulfate. After the first few weeks the displaced solutions made little further progress. The series reinforced with sulfate rielded about three times as mueh (ly matter as the natural soil solution, but only about one-fifth as much as the control. At Oregon Experiment Station sulfates have increased growth on lysimeter waters even where the untreated drainage water was changed frequently and where the sulfate concentration in the pereolate was similar to that obtained from displacing the same soil type. ${ }^{59}$

A similar experiment, to be reported clsewhere, dealt with the best salt for supplying calcium ion for alfalfa in partial solution cultures. 


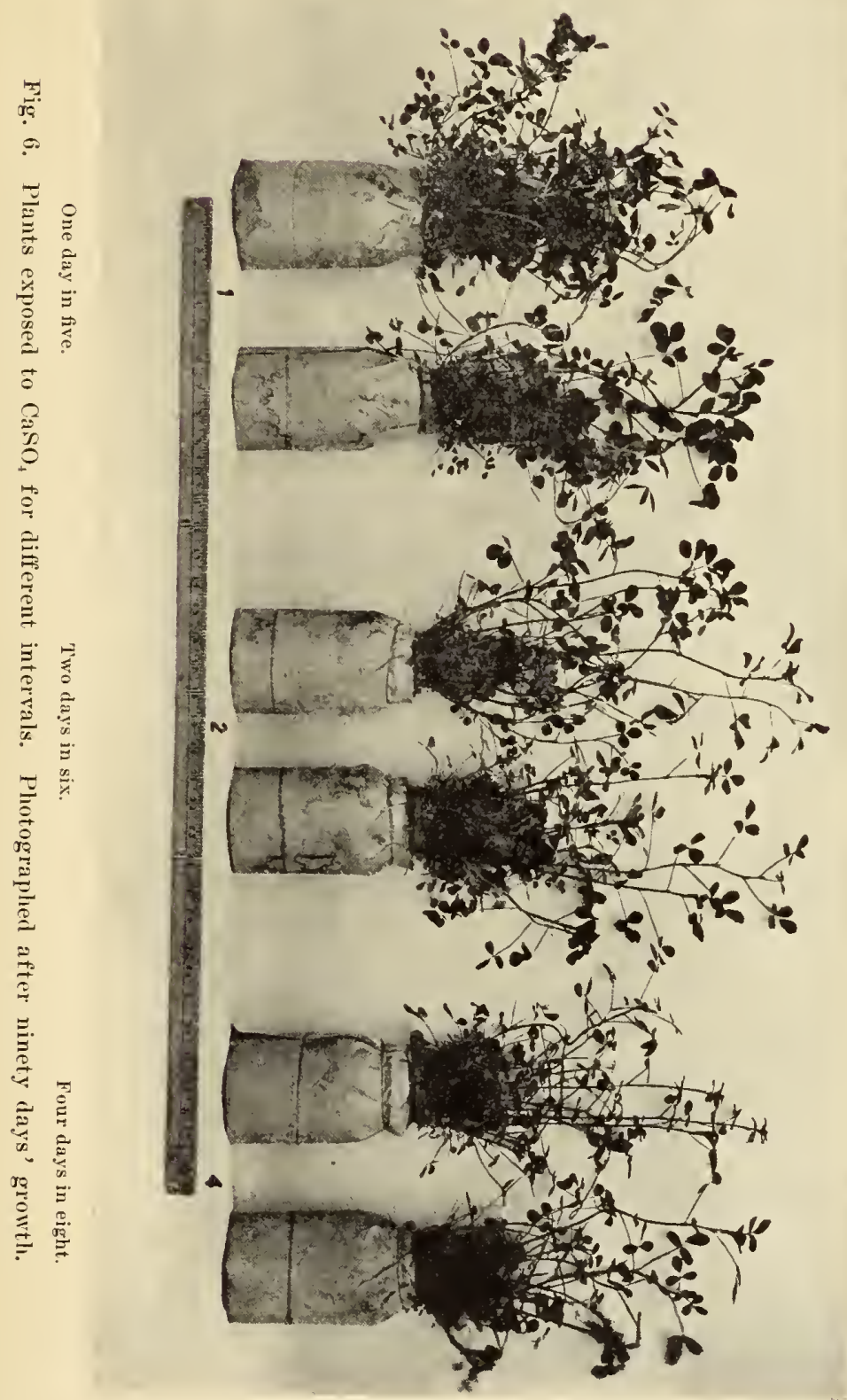


The largest yields were secured with calcium supplied as sulfate. A slightly lower yicld was secured with calcium nitrate, and much less with caleium phosphate. The mean weight of tops from six weeks' growth was $.96 \mathrm{gm}$. with calcium sulfate; $.80 \mathrm{gm}$. with ealcium nitrate, and .20 $\mathrm{gm}$. with ealcium phosphate.

\section{WHEN DOES ALFALFA MOST NEED SULFUR?}

\section{TABLE 6}

Six series of eultures were arranged to determine more definitely the time in the growth period up to the blooming stage when alfalfa makes the maximum demand for sulfur. Three series were started in complete solutions while thrce companion series were in sulfur-free solutions. After three weeks the first pair of series of plants was reversed as to sulfur supply. The second pair was interchanged after six weeks, the third pair at nine weeks. These plants were harvested after twelve weeks' growth. The adrantage of having sulfate supplied during the first six weeks of this growth period was still evident at harvest time, as shown by figure 7 .

In all three eases the plants started in the sulfur-containing solution gave higher yields. There was some indication of benefit in the case of plants removed from sulfur after six weeks, and there was less recovery from lack of sulfur where this clement was applied late in the growth period.

\section{TABLE 6}

At What Stage in Growth Periol of Alfalfa is Sulfur Most Needed? Twelve weeks' growtl period.

\begin{tabular}{|c|c|c|c|c|}
\hline \multirow{2}{*}{$\begin{array}{l}\text { Culture } \\
\text { series }\end{array}$} & \multirow{2}{*}{ Treatment } & \multicolumn{2}{|c|}{ Hean yield in grams } & \multirow{2}{*}{$\begin{array}{l}\text { Water } \\
\text { requirement } \\
\text { tops }\end{array}$} \\
\hline & & Whole culture & Tops & \\
\hline 28 & S first 3 weeks. & 39 & $2 \pm \pm 16$ & 430 \\
\hline $28 a$ & $S$ after 3 weeks & 3.3 & $2.3 \pm 15$ & 519 \\
\hline 29 & S first 6 weeks... & 36 & $24 \pm .12$ & 449 \\
\hline $29 a$ & $S$ after 6 weeks & 25 & $1.8 \pm .07$ & 714 \\
\hline 30 & si first 9 weeks... & 38 & $27 \pm 23$ & 411 \\
\hline $30 a$ & $S$ after 9 weeks & 32 & $2.1 \pm .12$ & 608 \\
\hline
\end{tabular}

Solutions used in this trial were changed each month and analyzed. The sulfate content for solutions containing an initial concentration of 672 parts per million of sulfate at the end of the first month's growth showed a decrease in concentration to 584 parts per million. The solution being renewed, it was decreased in concentration to 450 parts per million the seeund montl. A new solution was reduced 


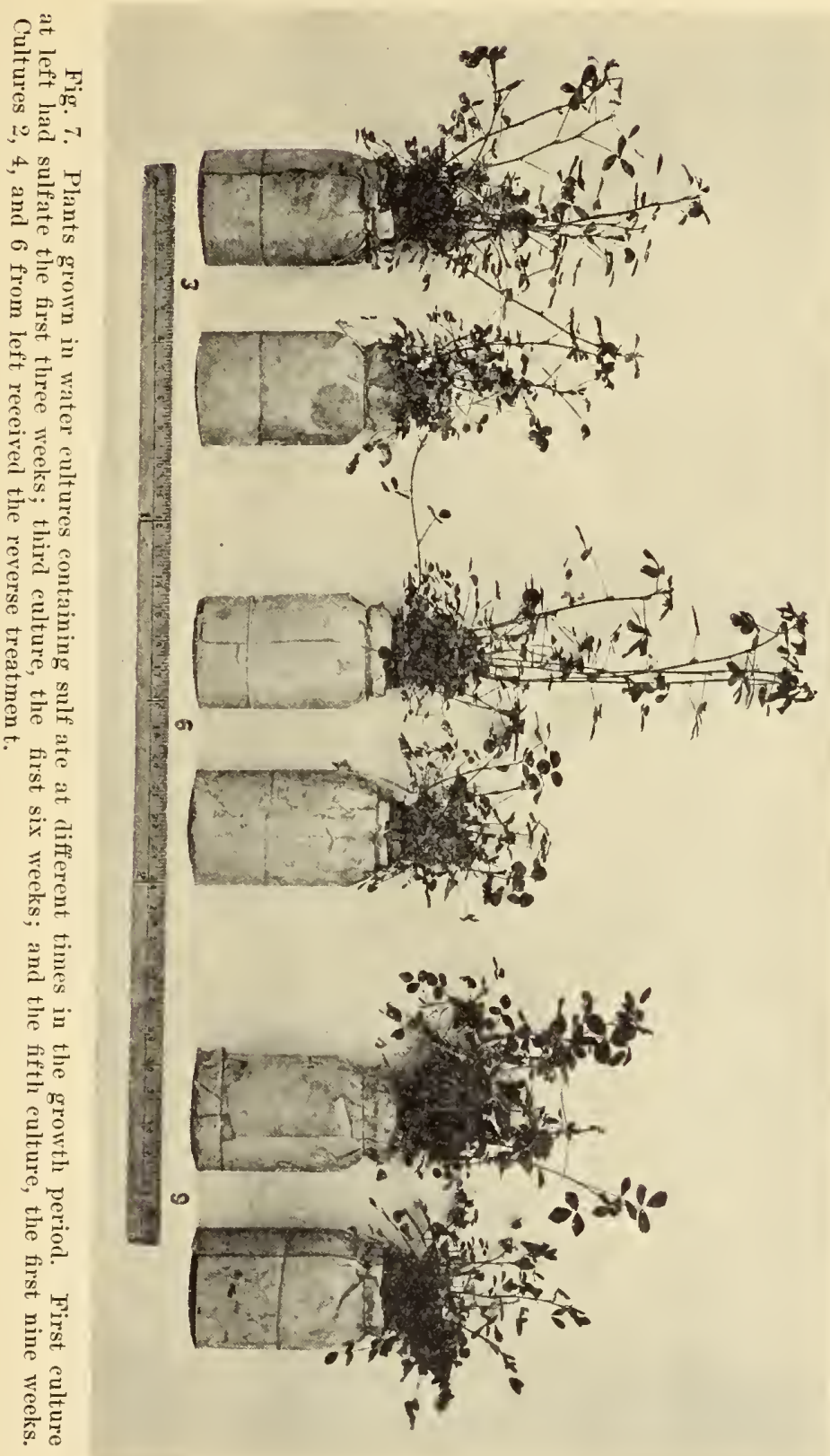


to 612 parts per million the third month. The maximum absorption of sulfur occurred in the second month and the minimum absorption in the third month. From all indications, plants seem to require sulfate largely during the earlier part of the growth period, presumably in building up their system after the seedlings have attained some size. Sulfur applieations may increase the sulfofying power of a soil and result in a more favorable concentration of sulfate ion at critical periods of growth. In all these experiments, providing a suitable sulfate supply gave a lower water requirement.

CROP-PRODUCING POWER OF LIMITED AMOUNTS OF SULFUR WITH ALFALFA

TABLE 7

Eight series of solution eultures were prepared, ineluding sulfurfree controls and solutions containing 5 to 30 parts per million of sulfur as calcium sulfate arranged in inerenents of 5 parts per million. One part per million is equiralent to 1 milligram per liter or practically the volume of aultures used. Maximum produetion per milligram sulfur seeured was .18 gms, alfalfa and with the solution

TABLE 7

Crop Producing Power of Limted Amounts of Sulfur

Dry matter yield in grams, six weeks' growtl.

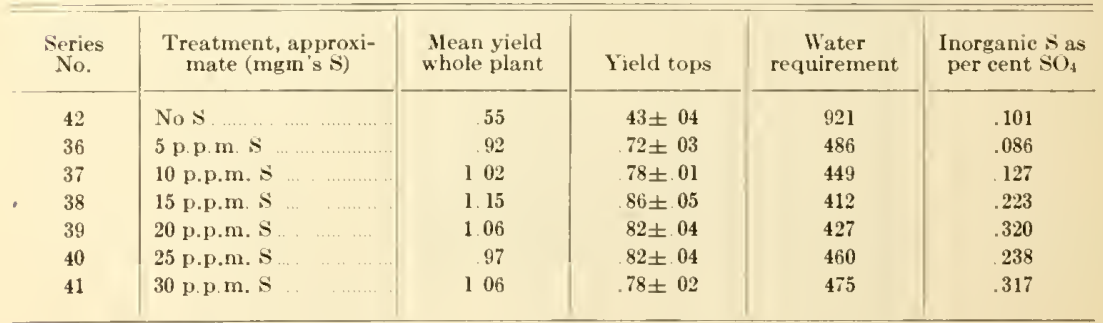

containing about 5 parts per million sulfur. Alfalfa plants were grown thereon and when a month old showed a general increase in growth up to the serics containing 15 parts per million of sulfur. With greater sulfate treatments the amount of growth was practically uniform. When the plants were six weeks old, 10 parts per million of sulfur appeared to be sufficient, as shown by figure 8 . The plants had attained 18 to 20 inches in height, and their requirement for sulfur appeared to be somewhat diminished. There was indieation of a slight stimulating effect with 10 parts per million compared to 


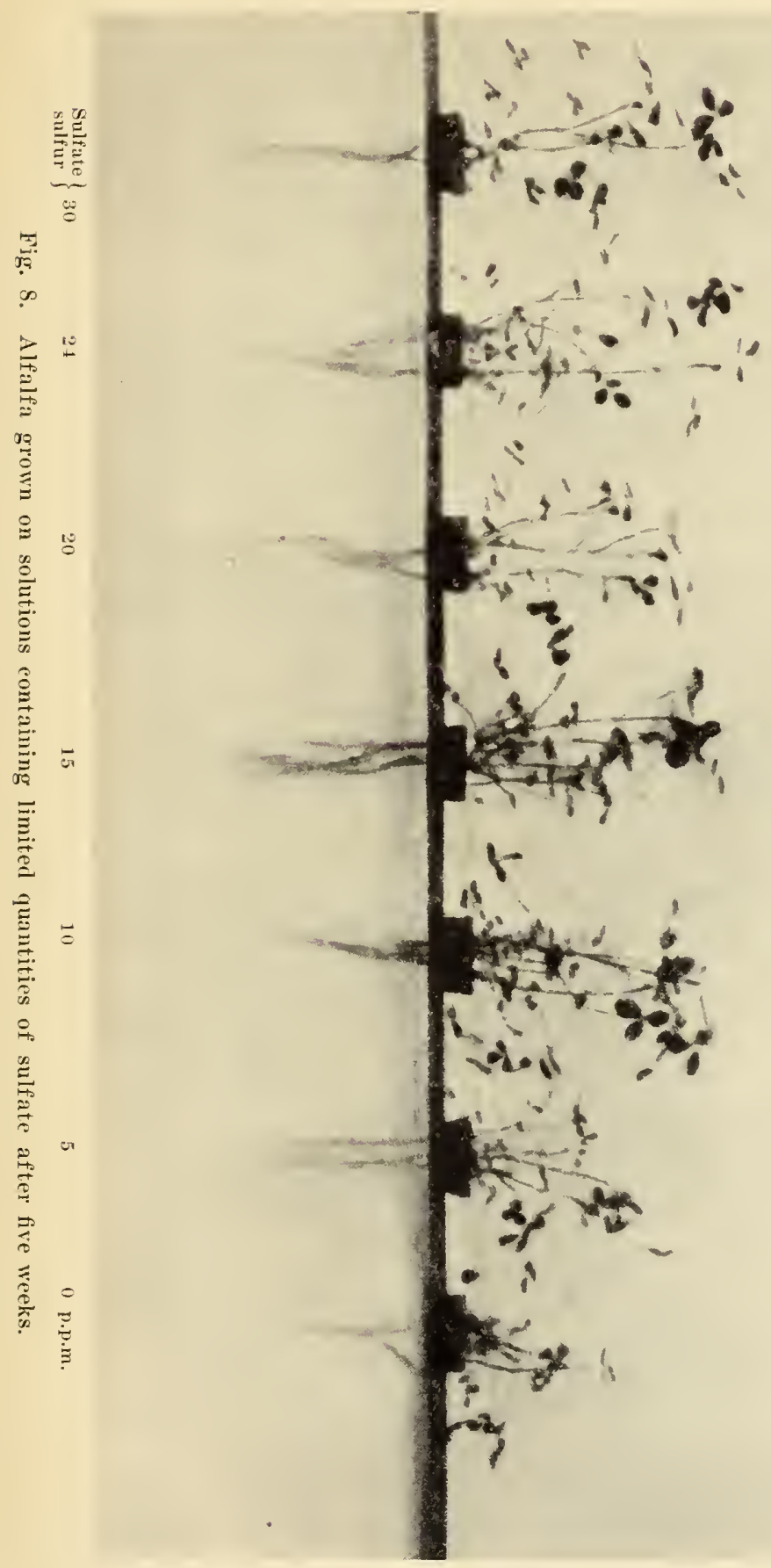


two or three times that amount at the later growth state, as shown by figure 9. It was necessary to harvest before the plants were two months old. The maximum yield was secured with 15 parts per million of sulfur in the solution. That there was no significant difference between this and the control or the serics receiving larger amounts of sulfate is slown graphically by figure 12. The sulfur-free solution there used was prepared from C. P. chemicals, but it was found to vield 1.6 p.p.m. sulfur in the eulture solutions as used.

Some soil solutions from Marlera sand were found to contain 150 parts per million of sulfate. Their usable water capacity was less than 10 per cent. An acre-foot of solution would not be stored in less than 10 acre-feet of such soil, giving 14 parts of sulfate per million in the total mass. In the soil, diffusion may be slower than in the culture solution.

The last column in table 7 gives the sulfate recovered by hot water extraction of plants grown in this experiment. A much larger amount of unassimilated sulfate appears to have been present in plants grown on solutions containing 15 p.p.m. or more of sulfur.

\section{CONCENTRATION OF SULFATE NEEDED FOR OPTIMUM GROWTH OF ALFALFA?}

Evidence on the least probable concentration needed for optimum growth is scarce. The concentration of different ions necessary in solution eultures or soil solutions is not definitely known.

Cameron $^{12}$ matured wheat in tap water which was claimed to contain 0.5 parts per million of phosphorus as phosphate ion.

Burd ${ }^{10}$ suggested that, as a result of crop removal, the concentration in a soil solution may fall below supplying the need of certain ions by plants. He reports a two-day nitrate supply as the lowest conecntration found under growing barley, as judged by the rate of erop removal. It is further suggested that crop removal may hasten solution from the solid phase of the system.

MeCall and Richards ${ }^{42}$ found a higher concentration necessary in quartz eultures to give equal effect with water cultures.

Iloagland and Martin ${ }^{2 \tau}$ point out that surtable concentration is affected by size of culture ressel, plants to be grown, rapidity of growth, reaction, and frequency of renewal of the solution.

In an experiment previously referred to, potassium sulfate greatly increased the yield of alfalfa grown on displaced soil solution, although 


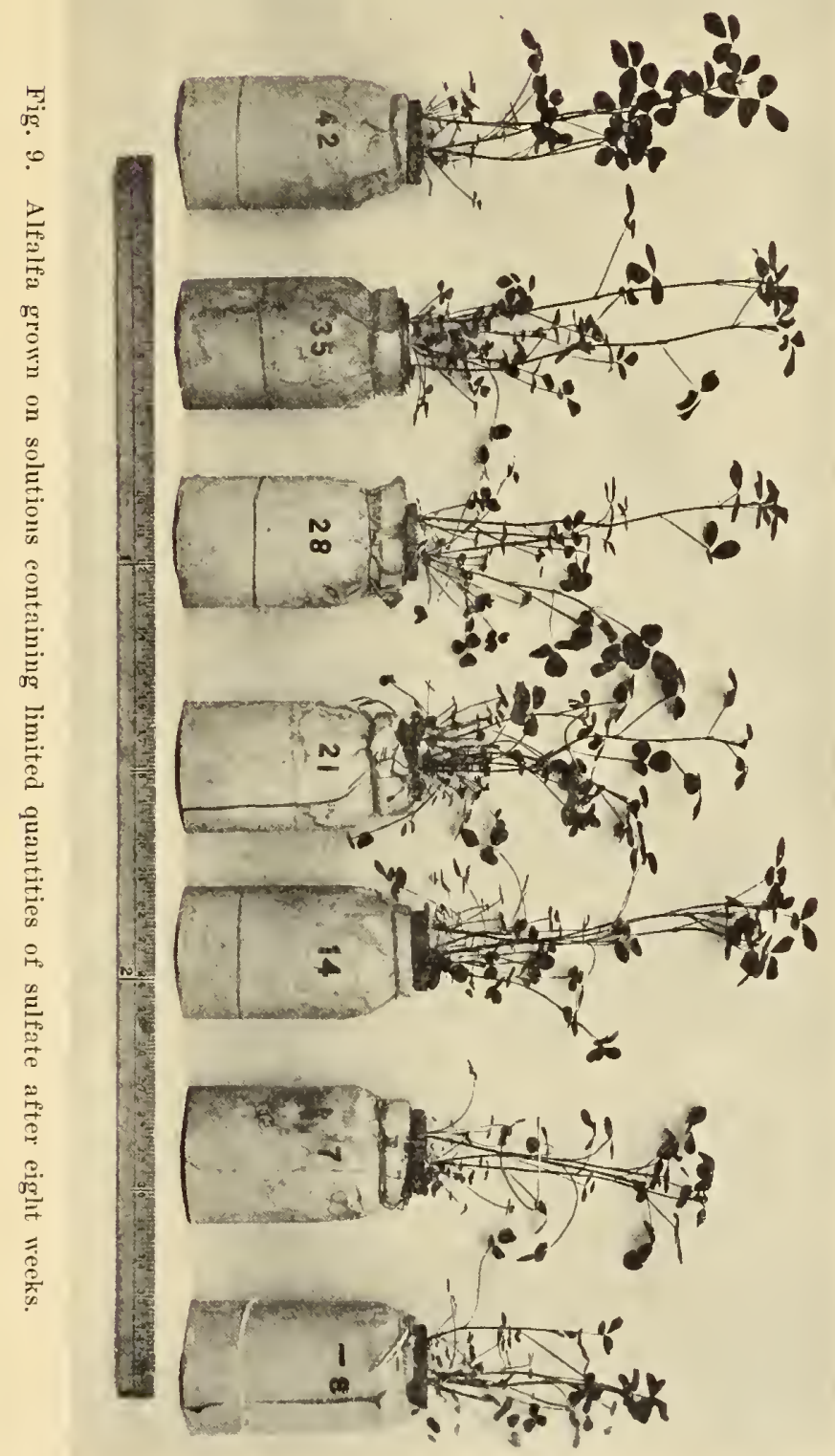


there was already an apparent abundanee of potassium present. Calcium sulfate or potassium nitrate inereased the yield of grain grown in lysimeter water in recent experiments at the oregon Experiment Station, ${ }^{59}$ even though the soil water was frequently renewed. The study of erop-produeing power of limited amounts of sulfate indieated that 10 to 15 parts per million of sulfur or 30 to 45 of sulfate might be needed for best growtl of alfalfa. Two soil solutions studied eontained 12 and 14 parts per million respeetively. An experiment was planned to test the concentration of sulfate needed for alfalfa in culture solutions, and also in a solid medium, as an aid in interpretation of soil solution analyses.

\section{SULFATE CONCENTRATION EXPERIMENT WITH CULTURE SOLUTIONS}

To study further the eoneentration of sulfate needed for optimum growth of alfalfa, a new experiment was planned in whieh four series of alfalfa plants were set up and grown in eaeh eoneentration of sulfate employed, so that one series from eaeh lot could be larvested at intervals of 10 days and subjected to chemical tests. Control series were arranged without sulfur and with complete nutrient solutions. The eoneentrations of sulfur in other series were $2,4,8,16,32$, and $6+$ parts per million, respectively. Within 10 days the plants without sulfur were making poorer growth than the remaining series. The plants lad been set on the jars when the fourth leaf appeared on the secdlings. Ip to 20 davs' growtl 16 parts per million of the element sulfur in sulfate form eaused a mole rapid growth than a lesser concentration. Before the 30 -day period a coneentration of 8 parts per million appeared to be sufficient and this condition obtained, so far as could be judged by height and appearanee of plants, to the elose of the experiment. The amount of growtl for different eoneentrations is indicated in figure 10.

\section{INORGANIC SULFL'R}

To arrive at a proeedure for studying the unassimilated or inorganic sulfate in different lots of these plants at different stages of growth, samples of alfalfa giown on field plats at Delhi were digested for 8 hours, in one case with hot, and the other with cold water. The pulp was filtered out, washed, and the extract acidified, redigested. and filtered free from protein. The sulfate was then preeipitated with barium ehloride, ignited, and weighed. Further tests were made 


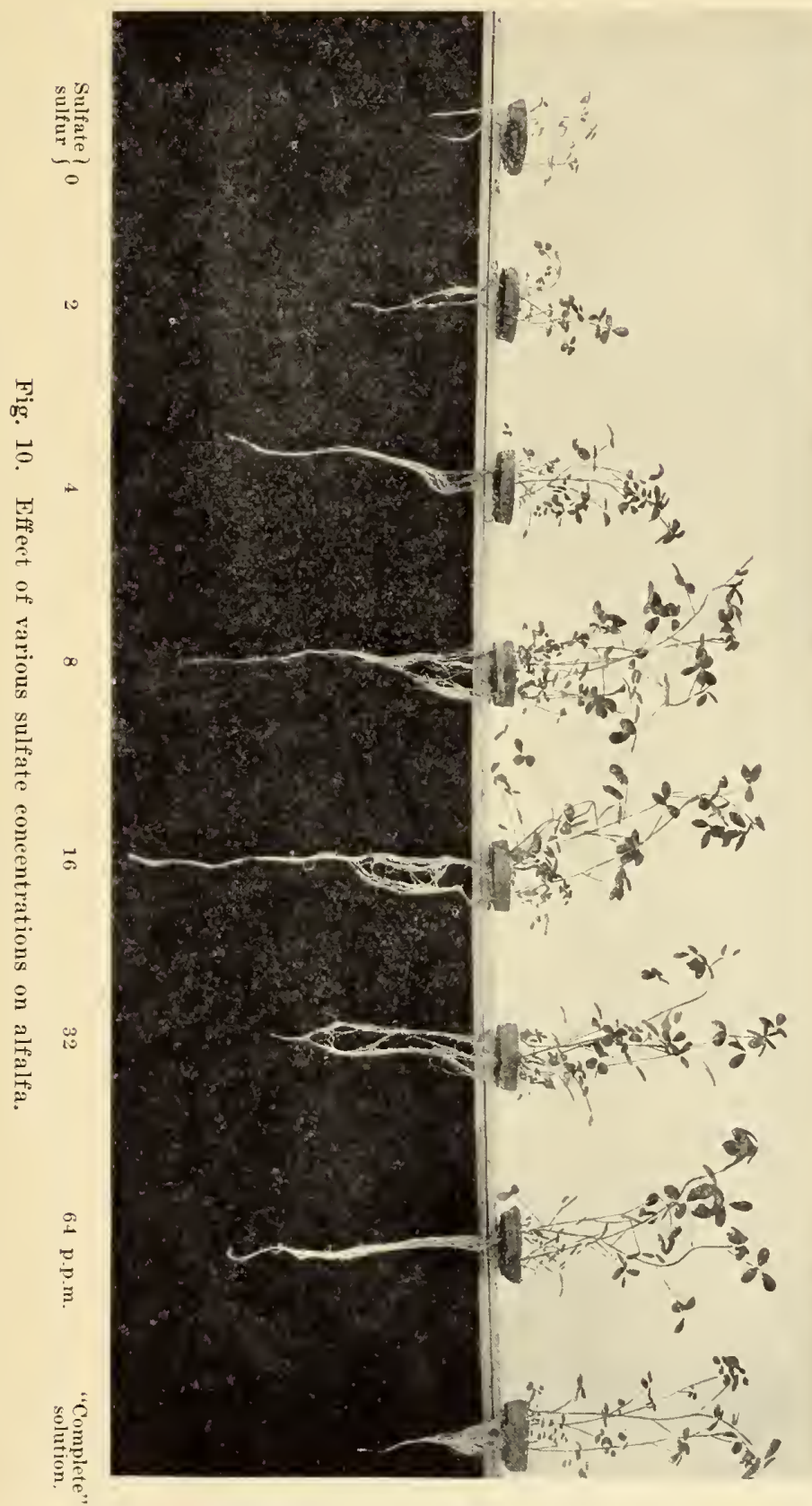


by an additional 4 hour's digestion of the pulp, which indicated that digestion with hot water for a period of 12 hours was desirable.

A second preliminary experiment was conducted on 1 gram portions of alfalfa meal diluted with water up to 10, 25, 50, and 100 times. Little advantage was found in diluting above 25 times and none above 50 times. Grimm alfalfa seed carried through this determination yielded 0.3 per cent of sulfate.

The alfalfa grown in water cultures with limited amounts of sulfate when analyzed by this method showed a rapid increase in sulfate content up to 15 parts per million, a further gradual increase up to 30 parts per million, and little or no inerease thereafter (table 7). In other words, the supply of inorganic sulfates in these young plants inereased with the growth eurve. Peterson ${ }^{48}$ and Hall ${ }^{20}$ seem to find only a small portion of sulfur in alfalfa plants in inorganic form. Determinations of organic sulfur from the residue of 30 day-old plants were made and indieate a reciprocal relation to the inorganic sulfur content.

YIELD AND INORGANIC SULFATE CONTENT AS AFFECTED BY SULFATE CONCENTRATION?

\section{TABLE 8}

In table 8 are presented the yield and the hot water extractable sulfate from alfalfa plants grown in solutions witl definite concentrations of sulfate, maintained by renewing the solution every three days. The yicld of dry matter in plant tops was increased by supplying sulfur up to 8 to 16 parts per million as sulfate in the solution. During the earliest part of the experiment 16 parts per million of sulfur scemed to give better growth than 8 parts per million. Later in the experiment the lower concentration appeared to be fairly adequate. Sulfate determinations imdieated that some cx-osmosis of sulfate oceurred for ligher eonecntrations the last 10 days of the trial. With these plants there was further evidenee of some stimulation about the least optinum concentration, as shown graphically in figure 13.

The sulfate extraetable in hot water inereased rapidly up to the least concentration necessary for optimum growth. A greater supply of inorganic, or hot water extraetable sulfate, was found in the plants at 30 days of age than at earlier or later growth periods. It appears that as fast as the plants gain some capaeity a considerable amount 


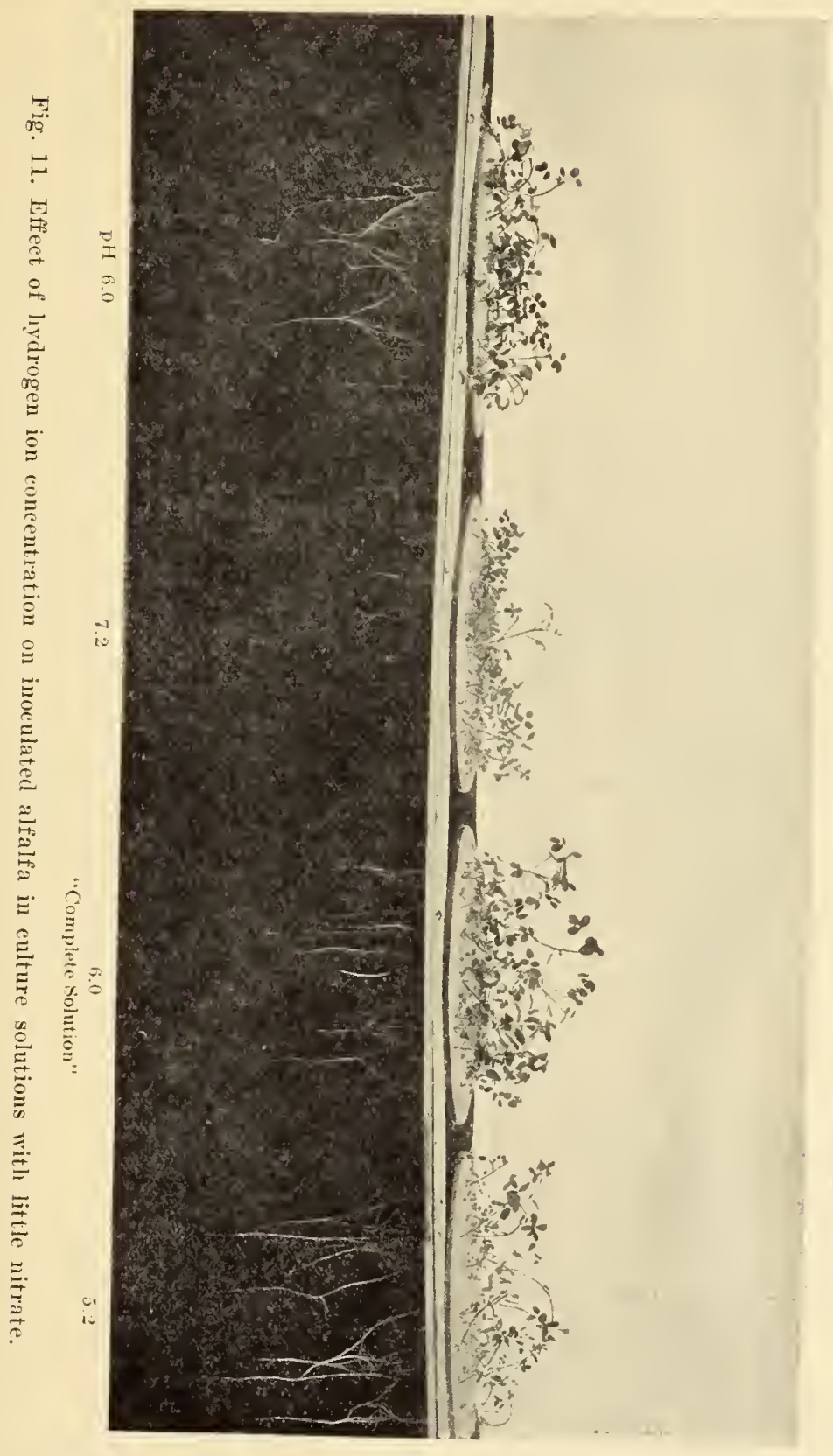




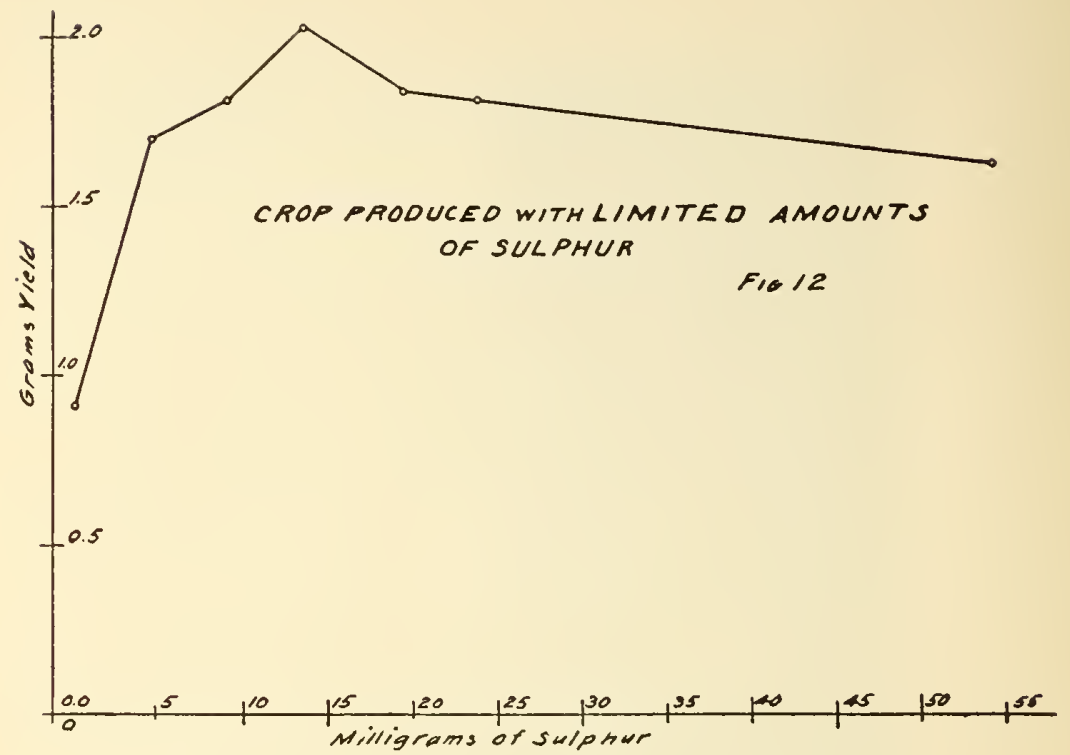

Fig. 12. Graph showing yield from limited amounts of sulfur.

EFFECT OF SULPHATE CONCENTATION ON THE YIELD OF ALFALFA FOR 30 DAYPERIOD

$F / 613$

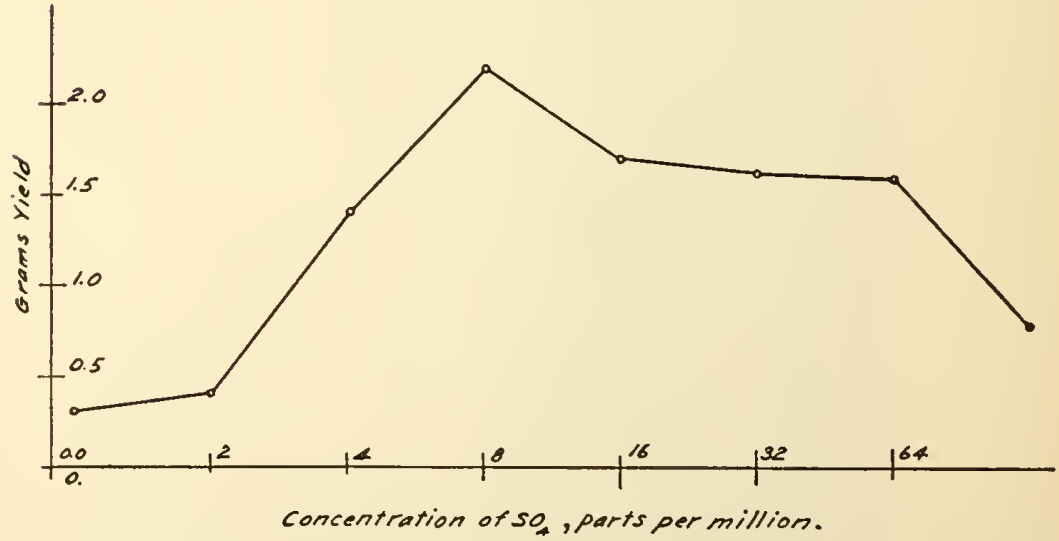

Fig. 13. Graph showing yield from eulture solutions maintained with different concentrations of sulfur. 
of sulfate is taken in, and later this sulfate is assimilated. Plants grown in the plant louse at the University of California were benefited rather than injured by removing them from a complete solution after the first six weeks to a solution lacking sulfate, and they appeared to have sufficient sulfate to carry them up to the blooming period.

TABLE 8

Effect of Sulfate Concentration of Culture Solution on Yield and Sulfate Content of Alfalfa at Different Stages of Growth

\begin{tabular}{|c|c|c|c|c|c|c|c|}
\hline \multirow{3}{*}{$\begin{array}{l}\text { Sulfur p.p.m, in } \\
\text { culture solution } \\
\text { (added as } \mathrm{CaSO}_{4} \text { ) }\end{array}$} & \multicolumn{4}{|c|}{ Mean yield in grams dry plant tops } & \multirow{2}{*}{\multicolumn{3}{|c|}{$\begin{array}{c}\begin{array}{c}\text { Plant sulfate extractable with } \\
\text { hot water, per cent }\end{array} \\
\text { Age of plants-days }\end{array}$}} \\
\hline & \multicolumn{4}{|c|}{ Growth period-days } & & & \\
\hline & 10 & 20 & 30 & 40 & 10 and 20 & 30 & 40 \\
\hline None & $01 \pm 001$ & $02 \pm 002$ & $05 \pm .006$ & $.09 \pm .002$ & 000 & 150 & .074 \\
\hline 2 & $01 \pm .00 \mathrm{I}$ & $.03 \pm .002$ & $07 \pm 003$ & $23 \pm 006$ & 068 & 652 & 291 \\
\hline 4 & $02 \pm 001$ & $.04 \pm 002$ & $23 \pm 005$ & $63 \pm$ & 217 & 750 & 285 \\
\hline 8 & $02 \pm .000$ & $09 \pm 005$ & $37 \pm 007$ & $.79 \pm .016$ & 440 & .886 & 255 \\
\hline 16 & $02 \pm 000$ & $.07 \pm 003$ & $28 \pm 005$ & $85 \pm 027$ & .506 & 1165 & 259 \\
\hline 32 & $02 \pm 001$ & $09 \pm 004$ & $28 \pm 007$ & $.79 \pm .018$ & .386 & 896 & 350 \\
\hline 64 & $02 \pm 001$ & $10 \pm .005$ & $27 \pm 011$ & $76 \pm .021$ & 929 & .975 & 448 \\
\hline Complete solution. & $02 \pm 004$ & $04 \pm .002$ & $14 \pm 003$ & $43 \pm 012$ & 979 & 1410 & 317 \\
\hline
\end{tabular}

From these studies it appears that 8 to 16 parts per million of sulfur or $2+$ to 48 parts per million expressed as sulfate, depending on age, is sufficient for best growth of alfalfa for these conditions. The sulfate contents of displaced soil solutions from a half-dozen representative Oregon soils (that have been included in sulfur experiments seven to ten years both with and without sulfur) reported above, throw further light on this problem.

\section{SULFATE CONCENTRATION EXPERIMENT WITI SOLID CULTLRE MEDIUM}

A parallel experiment was conducted in pots of quartz sand to note the effect of a solid medium on concentration and diffusion. Duplicate one-gallon jars of washed Ottawa silica sand were arranged so that, with the aid of an aspirator, solutions could be removed for renewal. Five alfalfa plants were grown in each jar. The yield was not increased with solutions containing more than 8 parts per million of sulfur. It is possible that transpiration changed the concentration of sulfate during the 3-day intervals between solution changes, although a little free liquid was present in the bottom of each jar. 
There may have been a concentration of sulfate at the surfaces of the quartz grains.

The rate of diffusion of sulfate ion may be expected to vary with a number of factors and a study is under way in quartz flour and quart $z$ sand.

Two lots of quartz flour and two of quartz sand moistened to the moisture equivalent point were placed in trays $25 \times 25 \times 60 \mathrm{~cm}$. The two sides, one moistened with $.01 \mathrm{~N} \mathrm{KCl}$, the other with $.01 \mathrm{~N}_{2} \mathrm{SO}_{4}$, were brought into contact and kept air tight at uniform temperature. In 45 days quantitative determinations of $1: 1$ extracts showed that sulfate had diffused + to $6 \mathrm{~cm}$. in the quartz flour and $8-10 \mathrm{~cm}$. in the sand. After 90 days a second test showed that diffusion had proceeded at a uniform rate. Apparently roots go to the nutrient more than nutrient goes to the roots. Concentration due to transpiration and surfaces may tend to eompensate for slower diffusion in solid medium than in solution cultures. Results indicate that a suitable sulfate concentration in medium sand is not greatly different from that needed in water cultures.

\section{REACTION STUDIES}

The reaction of the solutions used in the water culture studies above described was corrected almost daily where necessary, to keep it between pH 5.5 and 6.0, which appears to be most favorable for alfalfa in solution cultures. At or above pH 6.5 a lighter green color developed in tops and a brown eolor on roots. Below pII 4.8 roots became dull in appearance and growth was retarded.

One culture series, table $5, \bullet$. Was set with barley seedlings to compare the rate of change in reaction in a single salt solution of ammonium sulfate with grain to that intueed by alfalfa. The reaction became unfarorably acid with grain in about half the time required with alfalfa. Alfalfa removes sulfate from solution at about the same rate as ammonium ion and affords less opportunity for the sulfate radicle to accumulate in the solution and, by combination with water, to increase the concentration of lydrogen-ions.

'To learn more definitely the reaction best suited to inocnlated alfalfa, water culture solutions were prepared containing only 20 parts per million nitrogen and with different pll values, Eight

* This experiment was conducted in cooperation with Mr. Charles Hartmann, Jr., former Assistant in Soils, Oregon Agricultural Experiment Station. 
stoneware jars, each of 4-gallon capacity, were provided with covers so as to support 25 plants per jar and werc filled with nutrient solutions. Two jars were filled with "complete" nutrient solutions and adjusted to a pH valuc of 5.8. The other solutions were of similar salt proportions cxcept that little nitrate was present. 'The reaction was stabilized by addition of potassium acid thalate in all cases equiralent to 200 parts per million. Two jars were made up to pH 5.2, a second pair to $\mathrm{pH} 6.0$, and a third pair to pII 7.2. A fair growth was obtained in all but the alkaline solutions. 'The average yield for controls for 2 months' growth was .35 gram tops per plant. Cultures maintained at pII 7.2 yielded .13 gram of tops, and those kept at pH 5.2 yielded .21 gram tops per plant.

The greatest development of nodules occurred on roots of plants grown at pH 6.0. Nodules developed in the control the last wcek of the experiment. The range of $\mathrm{pH}$ in which alfalfa ean grow appears to be about pII 4.8 to 7.0 and to be wider than for alfalfa bacteria, which will not tolerate such an acid solution as will alfalfa. Mlfalfa appears to do best in a slightly acid culture medium. The equipment used and the comparative growth in different solutions after 5 wecks is shown in figure 11.

\section{DISCUSSION}

\section{Is Sulfate Concentration in Soil Solutions Somotimes} Too Low for Best Growth?

A study of gains and losses of soil sulfur, its oxidation, and the seasonal sulfatc concentration in the soil solution, strongly indicates that certain soils at times have an unfavorably low supply of this nutrient. Sulfate concentration in the soil solution is apparently more closely related to the sulfofying power of a soil than to its total sulfur content. Many northwestern soils, however, with only 150 to 400 pounds total sulfur in the plowed surfaee of an acre, respond to sulfur applications, while relatively few having more than 500 or 600 pounds of sulfur in 2,000,000 of surface soil give much response in the way of increased rield from sulfur applications. In the 1916 series of Reimer plats on Antelope clay adobe. near Medford. any sulfur-bearing fertilizer has strikingly increased alfalfa yields. Sulfur-free fertilizers supplying soluble phosphates, potassium, or nitrates have not materially increased yields. Moreover, calcium com- 
pounds in these trials have not eaused larger crops. ${ }^{50}$ These facts led to the view that many basaltie soils in the northwest were in need of sulfur per se. Studies herein reported have developed good evidence that unfavorably low concentrations of sulfate are less general than formerly supposed, yet they may be found at times in certain soils.

Reviewing the evidenee here presented, it is noted that eertain soil solutions were found which in certain cases vielded but 14 and 16 parts per million of sulfate. For a given set of conditions, the crop-producing effieiency of a limited amount of sulfur decreases below a eertain minimum. Sulfur in alfalfa seed seems to be insuffieient to develop properly and to mature alfalfa plants. Further, the least optimum concentration of sulfate for alfalfa appears to range from 48 to 24 parts per million during the early weeks of the growth period. The maximum demand and perhaps the whole need of sulfate, moreover, is met during these early weeks of the growth cycle, when sulfur oxidation on certain soils has been slow and sulfates in the soil may have been depleted by leaehing in the wet season. Diffusion in medium-textured soils may be much slower than in water culture solutions. Numerous faetors will affeet the concentration needed, as pointed out by Hoagland and Martin. ${ }^{27}$.Johnson's work ${ }^{31}$ seemed to indicate that reaction may affect sulfate absorption by plants from solution of low sulfate concentration; also, that acid or humid soil may supply sulfate needed from a lower eoncentration than that in neutral soils, and that sulfate production in soil is inereased by cropping. Diffusion will vary with temperature, surface tension, texture, and moisture content. Sulfate additions to eertain soil solutions and lysimeter waters ${ }^{59}$ used as eulture media for alfalfa and grain secdlings have increased the growth of these plants.

The majority of soils studied which respond to sulfur applications with alfalfa have 100 parts per million or more of sulfate. and other reasons for the marked increases in vields secured from this treatment must be found.

\section{Does sulfur Serve to Hold Calcium and Cther Bases in Solution?}

It has been noted in lysimeter studies at different experiment stations that there is a mutual effect of calcium and of sulfate on the composition of the percolate. Supplying either of these ions tends to increase the amount of the other found in a given amount of pereolate from lysimeters. ${ }^{59}$ 
The most striking and general effect of sulfur on the soil solution encountered in these experiments is the increase in concentration of calcium, following application of sulfur or sulfate. This has been true not only for fallowed pot experiments but for samples from sulfured and unsulfured field soils. In certain eases, as with Deschutes sandy loam, potassium concentration in the soil solution was greatly increased following sulfur treatment. Increase in magnesium in the soil solution is also noticcable following sulfur application. The calcium in solution is frequently doubled or trebled as a result of sulfur application.

Water culture experiments show that where sulfates of calcium, potassium, or magnesium are supplied to alfalfa plants in partial nutrient solutions, 2 days in 6 , calcium sulfate is the most favorable form and results in the largest amount of growth. Inversely, when calcium is supplied in partial solutions as sulfate, nitrate, or plrosphate, the calcium sulfate is a very favorable source of calcium.

The amount of readily soluble and of replaceable calcium and other bases present in a soil, as indicated by Kelley, ${ }^{33}$ is closely related to the composition of the soil solution. Madera sand, after 6 or 12 weeks of incubation with sulfur, was found to have released large amounts of ealcium to the liquid phase. The replaceable calcium in this soil is low and some carbonates probably were dissolved. A year later the amount of calcium in solution had greatly decreased and the potassium in solution had markedly increased. Either there had been a slow solubility effect on relatively insoluble potassium-bearing compounds in the solid phase, or, what is more probable, the calcium ion brought into solution from earbonates had participated in a base exchange with the base-absorbing complex of the soil.

An important function of sulfur or other anions, as pointed out recently by Burd," appears to be that of holding eations in solution and thus maintaining a farorable concentration of nutrients in the soil solution. Ile has suggested that when nitrate is largely remored by growing erops the sulfate operates to perform this function and to keep bases in available form. A t-ton crop of alfalfa requires about 300 pounds of calcium. ${ }^{32}$ The concentration of calcium ion in the soil solution for some of the soil types studied has been found to be as low as 20 or 30 parts per million at certain times. At present it appears that one of the leading effects of sulfur is to bring calcium and other bases into the soil solution and to hold them there. 


\section{Will the Average Applieation of Sulfur Hasten Soil Deterioration?}

Recent studies by Gedroiz ${ }^{17}$ and others indicate that the replaceable bases adsorbed by the soil-adsorbing complex of a fertile soil should be mainly calcium or the bivalent bases, calcium and magnesium. Further, that when this adsorbing complex becomes unsaturated with bases, as in aged acid soils, and contains much adsorbed lyydrogen ion instead, these complex silicates may tend to become unstable and to deteriorate into the simpler oxides, namely, iron, silica, and aluminum oxides. The result may be a denser structure and a loss of base-adsorbing capacity. Perhaps a similar condition may come about with a soil imporcrished of replaceable calcium in the case of a sodium-saturated, adsorbing complex with a "black alkali" condition, which may be a possible cause of "slick spots." It is conceivable that heavy and continued applications of sulfur may hasten removal of calcium ion and ultimately lead to soil deterioration, especially under conditions favorable for leaching. After an initial application, subsequent sulfur treatments are often effective if applied at a lighter rate. Where fertilized alfalfa is consumed on the farm and over-irrigation is avoided, the increase in organic matter caused by moderate applications (that is, 80 to 100 pounds an acre) of sulfur every 3 or 4 years may have little effect on soil deterioration. It would seem that the use of sulfur as a fertilizer may be more safely practiced on basaltic soils that are liberally supplied with different forms of calcium.

\section{Does Sulfur Improve Reaction of Arid Soils for Alfalfa?}

Nitrate is known to be taken into the plant better under slightly acid conditions, and sulfur may improve reaction for nitrate adsorption by alfalfa. Johnston seems to find ${ }^{31}$ that sulfate is taken up by alfalfa best when the pH value of the eulture medium is about 5.8. Iron and phosphate are known to be relatively insoluble under alkaline conditions. Sulfur tends to increase the solubility of these nutrients up to a point where the calcium dissolved begins to react and cause reprecipitation. Sulfur doubled the amount of iron in solution in Antelope clay adobe. Ferric clloride applied by spraying on young growth on this soil resulted in the same improvement in color and yield that has been characteristic of sulfur-treated plats.

In nutrient solutions correction of reaction by addition of dilute sulfuric acid secured larger growth and better color of alfalfa than resulted from addition of hydrochloric acid. This sulfate may have 
affected the form of iron in the culture solution or it may have acted directly. Possibly the chlorine in the small amount added was injurious. Alfalfa grows best in a slightly acid medium, as indicated by Theron ${ }^{57}$ and confirmed lerein. The best reaction for the alfalfaradicicola combination was found to be about pH 6.0.

Sulfur has been found effeetive in improving the reaction and structure of alkali soil at Kearney Park Experiment Field, California, and at Vale Experiment Field in Eastern Oregon. ${ }^{30}$ Sulfur application may result in improved permeability in alkali land, and. by improvement in soil structure or possibly by modifieation of surface tension, may render soil more drought-resistant.

There are numerous other effects of sulfur on physical, chemical. and biological conditions related to plant nutrition. The three factors discussed above have stood out as being of chief importanec in these studies with the sorl solution. Which of these effeets will be of major importance may depend on the particular soil and conditions at hand.

\section{SUMIIARY}

1. Sulfur and sulfates applied to Madera sand soil in pot tests caused marked increase in ealcium ion and a definite increase in other bases in the displaced soil solution. Caleium and sulfate ions go into the alfalfa plant especially well together.

2. Heavy applications of sulfur resulted in increased soil aeidity, which caused an increase in phosphate and iron content of the soil solution up to a certain point, after which bases dissolved or replaced tended to precipitate these two ions from the soil solution.

3. Heavy application of sulfur tended to inlibit nitrification, though the normal application, or 100 pounds per acre, on arid sorts may increase growth and nitrogen in the soil.

4. Evidence was found of base exchange as sulfur oxidation increased the concentration of hydrogen ion and then of other cations. Fixation and exchange of bases applied in sulfates, as in potassium sulfate, was noted.

5. Analyses of displaced soil solutions of several sulfured and unsulfured soils from fertilizer experiment fields tend to confirm results secured with Madera sand and further indicate that the sulfate content of some soils at certain seasons is very low. Further, that the effect of sulfur will depend much upon the partieular soil at hand. 
6. Sulfur is needed most by alfalfa during the early weeks of the growth period. Sulfur applications increase sulfofication and the sulfate content of the soil solution, and they may in turn serve to bring bases into solution, resulting in a more concentrated soil solution and decreased transpiration.

7. Water culture experiments indicate that a concentration of 48 to 24 parts per million of sulfate is most favorable for the growth of alfalfa under the conditions of the trial. The maximum production seeured per milligram of sulfur was .18 gm. alfalfa and was produced with a solution having an initial sulfate content of 15 parts per uillion.

8. An a verage application of sulfur appears to improve the reaction of arid soils for alfalfa nutrition, resulting in increased growth and higher chlorophyll and sulfate content.

9. It is concluded (a) that some soils may have a sulfate content which is unfavorably low for best growth of alfalfa, especially early in the growth period; $(b)$ that sulfur oxidizes to sulfate and brings additional calcium and other bases into solution; $(c)$ that sulfur in moderate amounts improves the reaction of arid soils for alfalfa mutrition; (d) that the sulfur applications which are of greatest benefit will depend on the soil at hand; and (c) that ordinary applications of sulfur for alfalfa on the arid basaltic soils or soils liberally supplied with calcium compounds is probably good practice, especially where the growth secured is consumed on the farm. 


\section{LITERATURE CITED}

I ADAMS, HENRY R.

1924. Some effects of sulfur on crops and soils. Soil Sci., rol. 24, pl). 111-15.

2 Ames, J. W., and Richmond, T. E.

1918. Sulfofication in relation to nitrogen transformations. Soil Sei., vol. 5 , pp. 311-21.

3 A MES, J. E., and BoLTz, G. E.

1916. Sulfur in relation to soils and erops. Ohio Agr. Exp. Sta. Bul., vol. 292 , PP. $219-56$.

4 Boullanger, E., and Dugardin, M.

1912. Mechanisme de l'action fertilisante du soufre. C.-R. Acad. Sci. Paris, vol. 15.5, pp. 327-29.

5 Brown, P. E., and Gwis, A. R.

1917. Effects of sulfur aud manure on availability of rock phosphate in soil. Iowa Agr. Exp. Sta., Res. Bul. 43.

6 Brown, P. E., and JoHnson, H. W.

1916. Studies in sulfofication. Iowa Agr. Exp. Sta., Res. Bul. 34.

7 Brown, P. F., and Kellogg, E. H.

1914. Sulfofication in soils. Proc. Iowa Acad. Sci., vol. 21, 1'p. 17-22.

8 Burd, J. S., and MARTiN, J. C.

1924. Secular and seasonal changes in the soil solution. Soil Sci., vol. 18, pp. $151-67$.

9 BURD, J.S.

1925. Relation of liological processes to cation concentration in soils. Soil Sci., vol. 20, pp. 269-83.

10 BURD, J. S.

1919. Rate of absorption of soil constituents at suecessive stages of plant. growtl. Jour. Agr. Res., vol. 18, 1p. 51-72.

11 Burd, J. S., and MARTiN, J. C.

1923. Water displacement of soils and the soil solution. Jour. Agr. Sci., rol. 13, pp. $26.5-95$.

12 CAMERON, F. K.

1911. The soil solution (The Chem. Pub. Co., Easton, Pa.), 70 Pp.

13 C'HAUZET, J.

1921. L'action fertilisante du soufre. Bul. de l'Academie d'Agriculture, Paris, vol. 7, pp. 492-93.

14 Davis, A. R.

1921. The variatibility of plants grown in water culture. Soil Sci., rol. 11, pp. $1-32$.

15 D'Ippolito, G.

1923. Experimental studies on the fertilizing effect of sulfur. In Le Stazioni Sperimentali Agrarie Italiane, vol, 56, pp. 512-20. Reviewed in Soil Sci., vol. 19, p. 82. 
16 ERDMAN, L. W.

1923. Effeets of gypsum on Iowa soils. Soil Sei., vol. 15, pp. 137-5̃.

17 Gedroiz, K. K.

1924. Soils unsaturated witl bases. In Zlrur. Opit. Agron. (Jour. Exp. Agron.), vol. 22, pp. 3-27. Page 3, mimeographed trauslation by S. Waksman, for Bur. Pl. Ind., U. S. Dejt. Agr.

Is GERICKE, IV. F.

1922. On the physiologieal balance in nutrient solutions. Am. Jour. Bot., vol. 9 , pp. $180-82$.

19 Gerlach, M.

1910-1911. Untersuchungen uber die Menge und Zusammensetzung der Sickenwasser. Mitteil. Kaiser Wilhelm Inst. Landw. Bromberg, vol. 2 (1910), pp. 319-87; vol. 3 (1911), pp. 351-81.

20 HALL, F. H.

1922. Sulful and nitrogen content of alfalfa grown under various conditions. Bot. Gaz., vol. 73, pp. 401-11.

21 Halverson, IV. Y'., and Boleen, W. B.

1923. Studies on sulfur oxidation in Oregon soils. Soil Sci., vol. 16, pp. $479-90$.

2. Hart, E. B., and Tottinghair, W. E.

1915. Relation of sulfur compounds to plant nutrition. Jour. Agr. Res., vol. 5, pp. $233-50$.

23 Hart, E. B., and Peterson, W. H.

1911. Sulfur requirement of farm erops in relation to soil and air supply. Univ. Wis. Agr. Exp. Sta., Res. Bul. 14.

24 IlArris, J. A., et $a l$.

1925. Sulfate content of leaf tissue fluids of Egyptian and upland cotton. Jour. Agr. Res., vol. 31, pp. 658-60.

25 HibBard, P. L.

1924. Methods of amalysis (mimeographed), pp. 72-78.

26 Hibbard, P. L.

1921. Sulfur for neutralizing alkali soil. Soil Sei., vol. 11, pp. 385-87.

27 Hoagland, D. R., and Martix, J. C.

1923. A comparison of sand aud solution cultures with soils as media for plaut growth. Soil Sei., vol. 16, pp. $367-88$.

28 IIOAGLAND, D. R.

1919. Relation of concentration and reaction of the nutrient medium to the growtl and absorption of the plant. Jour. Agr. Res., rol. 18, pp. $73-117$.

29 JOFFE, J. S.

1922. Acid phosphate production ly the Lipman process. Soil Sei., vol. 14, l'p. 479-92.

30. Johnston, W. W., and 1'owers, W. L.

1924. Alkali land reclamation investigations. Oregon $\mathrm{Igr}$. Exp. Sta., Bul. 210.

31 JOHNSTON, W. W.

Studies of rate of sulfate formation and intake by plants. Mamuseript. 
32 JONES, J. S.

1923. Chemical study of legumes and other forage crops. Oregon Exp. Sta., Bul. 197.

33 Tíelley, W. T'.

1924. Replaceable bases in soil. Unir. Calif. Agr. Exp. Sta., Tech. Paper 15.

34 LIPMAN, C. B., and Gericke, W. F.

1916. The significance of the sulfur in sulfate of ammonia applied to certain soils. Soil Sci., vol. 5, pp. 81-86.

35 Lipdin, C. B., and Gericke, W. F.

1918. Does calcium carbonate and calcium sulfate treatment affect the solubility of the soil's constituents? Univ. Calif. Publ. Agr. Sici., vol. 3, PP. 271-82.

36 LIPMIAN, J. G.

1916. Sulfur on alkali soils. Soil Sei., vol. 2, p. 205.

37 Liphax, J. G., Prince, A. L., and Blair, A. W.

1921. The influence of varying amounts of sulfur in the soil, on crop yields, hydrogen ion concentration and lime requirements and nitrate formation. Soil Sci., vol. 12, pl. $197-207$.

38 LIPMAN, J. G., and MCLEAN, II. C.

1918. Experiment with S-P compost under field conditions. Soil Sci., vol. 5 , pl. $248-50$.

39 Macintire, W. E., Shaw, W. M., and Young, J. B.

1923. Influence of calcio and magnesia additions upon the outgo of sulfates from a loam soil as measured by lysimeter leachings over an eightyear period. Soil Sei., vol. 16, pp. 1-40.

40 Macintire, W. E., Shaw, W. M., and Young, J. B.

1923. Influcnce of calcio and magnesia additions upon the outgo of sulfates from a soil alone and with addition of ferrous sulfate, pyrite and sulfur. Soil Sci., vol. 16, 1']. 159-82.

41 MeCali, A. G, and Smith, A. M.

1920. Effect of sulfur composts on availability of postassium of greensand. Jour. Agr. Res., vol. 19, pp. 239-56.

42 McCall, A. G., and Richards, P. E.

1918. Mineral food requirements of the wheat plant at different stages of its development. Jour. Am. Soc. Agron., vol. 10, pp. 127-34.

$43 \mathrm{MCCOoL}, \mathrm{M} . \mathrm{M}$.

1920. The use of sulfur on soils. Mich. College Sta. Quart. (Aug., 1920), p). $26-28$.

44 Meyerhoff, O.

1925. Chemical dynamies of life phenomena (J. B. Lippineott Co., Phila.), chap. 2.

45 Miller, Harry G.

1921. Further studies on relation of sulfates to plant growth and comprosition. Jour. Agr. Res., vol. 22, Pp. 101-10.

46 Olson, Geo. A.

1921. Investigatiou of sulfur as a plant food. Wasl. Agr. Exp. Sta., Bul. 165. 
47 ONSLow, M. W.

1920. Practical plant biochemistry (Cambridge University Press), 135 pp. 48 Peterson, W. H.

1914. Forms of sulfur in plant materials and their variations with soil supply. Jour. Am. Chem. Soe., vol. 36, pp. 1290-1300.

49 Pitz, W.

1916. Effect of elemental sulfur and calcium sulfate on certain of the higher and lower forms of plant life. Jour. Agr. Res., vol. 6, 771-80.

50 Powers, W. L.

1924. Sulfur in relation to soil fertility. Oregon Agr. Exp. Sta., Bul. 199.

51 REIMER, F. C., and TARTAR, H. V.

1920. Sulfur for alfalfa in southern Oregon. Oregon Agr. Exp. Sta., Bul. 163.

52 Robinson, R. H., and Bulits, D. E.

1922. Acid soil studies, III. Influence of calcium carbonate, calcium oxide, and calcium sulfate, on the soluble constituents of acid soils. Soil Sei., rol. 13, pp. 449-59.

53 Robertson, T. B.

1920. The physical chemistry of proteins (ed. 2; Longmans, Green Co., London), $159 \mathrm{pp}$.

54 Rudolfs, W.

1922. Sulfur oxidation in 'black alkali' soils. Soil Sci., rol. 131, 215-29.

55 SCOFFIELD, CARL S.

1912. Effect of alum on silicate colloids. Jour. Wash. Acad. Sci., rol. 2, pp. 438-39.

56 Stephenson, R. E., and Powers, W. L.

1924. Effeet of sulfur oxidation on solubility of soil ninerals. Soil Sci., rol. 18 , pp. $317-21$.

$5 \pi$ Theron, J. J.

1924. Influence of reaction on inter-relations between the plant and its culture medium. Unir. Calif. Publ. Agr. Sci., vol. 4, pp. $413-44$.

58 W ARBURG, O.

1925. Iron the oxygen earrier of respiration ferment. Sei., vol. 61, p.1588.

59 Unpublished data, Oregon Agr. Exp. Sta. 